OPEN ACCESS

Edited by: Miguel Montoro Girona,

Université du Québec en Abitibi-Témiscamingue, Canada

Reviewed by: Niina Kuosmanen, University of Helsinki, Finland Normunds Stivrins,

University of Latvia, Latvia

*Correspondence: Tasneem Elzein tasneem.elzein@gmail.com

Specialty section: This article was submitted to Paleoecology,

a section of the journal

Frontiers in Ecology and Evolution

Received: 29 February 2020

Accepted: 06 May 2020

Published: 09 June 2020

Citation:

Elzein T, Arseneault D, Sirois $L$ and Boucher Y (2020) The Changing Disturbance Regime in Eastern Canadian Mixed Forests During the 20th Century.

Front. Ecol. Evol. 8:156. doi: 10.3389/fevo.2020.00156

\section{The Changing Disturbance Regime in Eastern Canadian Mixed Forests During the 20th Century}

\author{
Tasneem Elzein ${ }^{1 *}$, Dominique Arseneault ${ }^{1}$, Luc Sirois ${ }^{1}$ and Yan Boucher ${ }^{2}$ \\ ${ }^{1}$ Département de Biologie, Chimie et Géographie, Université du Québec à Rimouski, Rimouski, QC, Canada, ${ }^{2}$ Direction \\ de la Recherche Forestière, Ministère des Forêts, de la Faune et des Parcs, Québec, QC, Canada
}

How strong was the anthropogenic imprint in the disturbance regime of eastern Canadian mixed forests during the 20th century? And how did it alter the tree species composition? To answer these questions, we reconstructed the 20th century anthropogenic disturbance regime and analyzed its impact on modern forest composition using historical and modern forest inventory and map data. Between 1895 and 2005 , an equivalent of $144 \%$ of the study area has been logged and $19 \%$ burned. The logging rotation period has shortened from 152 years in 1895-1935 to 47 years in 1965-2005, due to increased industrial capacity. The fire rotation period decreased from 1668 years in 1895-1925 to 200 years during the peak of human settlement (19251955), and then increased to 2925 years in 1955-2005. The geographical progression of anthropogenic disturbances in the landscape has reflected the socio-economic context. During the 20th century, logging moved inland from the margins of the main water courses, reflecting the shift in wood transport from log driving on rivers to the densification of the road network in the second half of the 20th century. Most fires were located at low altitude, close to private lands suggesting ignitions from anthropogenic origins. Fire prone species (poplars) are mostly found within burned areas. Despite these disturbances, forest composition remained relatively stable, suggesting resilience of regional forest ecosystems.

Keywords: anthropogenic, disturbances, mixed forests, composition, disturbance characteristics

\section{INTRODUCTION}

Land use practices have become an important driver of forest ecosystem dynamics at several spatial scales since the onset of the industrial revolution. Present-day forests worldwide must cope with human related increase of disturbance frequency, intensity, and extent (Foster et al., 1998; Steffen et al., 2004; Foley et al., 2005; Ellis et al., 2010; Danneyrolles et al., 2019). These anthropogenic disturbances trigger shifts in disturbance regimes (Frelich, 2002), which in turn alter the composition and structure of forest communities and landscapes (Houghton, 1994; White and Jentsch, 2001; Foster et al., 2003; Nowacki and Abrams, 2015; Trumbore et al., 2015; Danneyrolles et al., 2019). Anthropogenic fires and logging represent increased large scale mortality compared to preindustrial background levels (Trumbore et al., 2015). Thus, it is important to document how human activities have modified the disturbance regime in forest ecosystems and their consequent impact on forest composition and structure. 
At the interface of boreal and deciduous biomes in eastern North America, forest landscapes have been subject to intensive industrial logging and settlement fires for more than a century (Foster et al., 1998; Lorimer, 2001; Blanchet, 2003; Friedman and Reich, 2005; Boucher et al., 2009b, 2014). While, the preindustrial disturbance regime in this region was dominated by windthrows, insect outbreaks, rare natural fires, and anthropogenic fires of debated frequency and intensity (Fahey and Reiners, 1981; Frelich and Lorimer, 1991; Williams, 2000; Lorimer and White, 2003; Simard et al., 2006; Blarquez et al., 2018), logging has become one of the main causes of tree mortality in the post-industrial landscape (Canham et al., 2013). Logging creates large open sites suitable for early successional tree species colonists. As a result, it has shifted overstory tree composition from uneven aged, old growth and shade-tolerant stands to even aged, young, shade-intolerant stands (Keenan and Kimmins, 1993; Foster et al., 1998; Fuller et al., 1998; Abrams, 2003; Boucher et al., 2009c; Danneyrolles et al., 2019). Relative to pre-industrial conditions, post-industrial forests often show an increase in sugar maple (Acer saccharum) (Brisson and Bouchard, 2003; Dupuis et al., 2011; Terrail et al., 2019), red maple (Acer rubrum) (Whitney, 1994; Whitney and DeCant, 2003), poplars (Populus spp.) (White and Mladenoff, 1994; Foster et al., 1998; Fuller et al., 1998; Leahy and Pregitzer, 2003), and white birch (Betula papyrifera) (Siccama, 1971; Whitney, 1994; Abrams, 1998; Bürgi et al., 2000; Hall et al., 2002; Leahy and Pregitzer, 2003; Dupuis et al., 2011), while shade tolerant species like white spruce (Picea glauca) and northern white cedar (Thuja occidentalis) have generally decreased (Jackson et al., 2000; Friedman and Reich, 2005; Boucher et al., 2006; Dupuis et al., 2011).

Although anthropogenic disturbances in the 19th and 20th centuries have combined with pre-industrial disturbances, their characteristics (rotation period, size, frequency, disturbance interval, and spatial pattern) are often poorly documented compared to the pre-industrial disturbance regime. Similarly, the link between anthropogenic disturbances and long term forest compositional changes has often been suggested, rather than demonstrated, because of the lack of data allowing spatially explicit reconstructions of disturbance regime and landscape composition. In this study we used archival ( 1920) and modern forest maps and forest inventory plots to reconstruct the spatially explicit history of the post-industrial anthropogenic disturbance regime and parallel forest composition changes of the 20th century in a large area $\left(3217 \mathrm{~km}^{2}\right)$ of the eastern Canadian mixed forest. More specifically, our main objective is to quantify the main parameters (spatial pattern, rotation period, and extent) of the anthropogenic disturbance regime of the 20th century and evaluate what was the relative influence of these anthropogenic disturbances on the development of present-day vegetation?

\section{MATERIALS AND METHODS}

\section{Study Area}

The study area is located in the Lower Saint Lawrence Region (LSL) in the south-east of the province of Quebec, Canada $\left(47^{\circ} 92^{\prime} \mathrm{N}\right.$ to $48^{\circ} 91^{\prime} \mathrm{N}$ and $66^{\circ} 84^{\prime} \mathrm{W}$ to $\left.68^{\circ} 86^{\prime} \mathrm{W}\right)$.
It is delineated to the north by the St. Lawrence River and to the south by the province of New Brunswick and lies within the Appalachian geological formation, characterized by sedimentary bedrock. The topography generally consists of low elevation hills with moderate slopes with mean and maximum elevations of $350 \mathrm{~m}$ and $910 \mathrm{~m}$, respectively. Surface deposits are mainly from glacial and in situ weathering origins. The meteorological data (1981-2010) of Rimouski (20 m a.s.l.), Trinité-des-Monts (260 m a.s.l.), and Saint-Jean-de-Cherbourg (320 $\mathrm{m}$ a.s.l.) (Figure 1) show mean annual temperatures of $4.4^{\circ} \mathrm{C}, 2.5^{\circ} \mathrm{C}$, and $1.9^{\circ} \mathrm{C}$ and annual total precipitations of $959 \mathrm{~mm}, 1100 \mathrm{~mm}$, and $1138 \mathrm{~mm}$, respectively, 30\% of which falls as snow (Environment Canada, 2019).

This area is situated at the northern limit of the Great Lakes-St. Lawrence mixed forests at the transition between the temperate deciduous and the boreal coniferous forests (Rowe, 1972). Up to $75 \%$ of the study area corresponds to public forest, mostly in the backcountry, whereas $25 \%$ is private land, mostly along the St. Lawrence River. The study area is composed of two former forest concessions of the Price Brothers \& Company: the Rimouski $\left(2279 \mathrm{~km}^{2}\right)$ and Matane $\left(938 \mathrm{~km}^{2}\right)$ sectors. Price Brothers \& Company operated in the LSL region since the 19 th century until the first half of the 20th century. The two sectors belong to the balsam fir-yellow birch bioclimatic domain (temperate mixedwoods), although the south-eastern part of the Matane sector, which is higher in elevation with steeper slopes, is located in the balsam fir-white birch domain (southern boreal forest) (Robitaille and Saucier, 1998; Grondin et al., 1999). Balsam fir (Abies balsamea), white spruce, and yellow birch (Betula alleghaniensis) are abundant in mesic sites in the balsam fir-yellow birch bioclimatic domain, while balsam fir, white spruce and white birch are abundant in mesic sites in the balsam fir-white birch domain. In both domains, trembling aspen (Populus tremuloides) and balsam poplar (Populus balsamifera) are also present. Sugar maple and red maple generally occupy hill tops and reach their northern range limit in the study area. Black spruce (Picea mariana) and northern white cedar generally occur on organic deposits along water courses (Robitaille and Saucier, 1998).

The study area has been subject to extensive anthropogenic fires, logging practices of increasing severity and spruce plantations during the 19th and 20th centuries. Fires were frequent at the margins of inhabited areas during the early 20th century due to slash burning for land clearing and agriculture (Fortin et al., 1993; Terrail et al., 2019). In the second half of the 20th century, population stabilization and effective fire suppression (Blanchet, 2003) decreased the frequency of fires to very low values. Logging practices during the 19th century and until the 1930s were mainly selective winter harvesting of large pine and spruce trees (Fortin et al., 1993; Boucher et al., 2009a). Logs were then transported to saw mills using water courses (Proulx, 1985). Forest operations slowed down during the great economic depression of 1929-1939 and vigorously recovered following the Second World War due to the increasing demand for residential construction material. In the 1940s, the rarefaction of large diameter trees prompted a progressive transition to the pulp and paper industry exploiting smaller diameters of spruce 


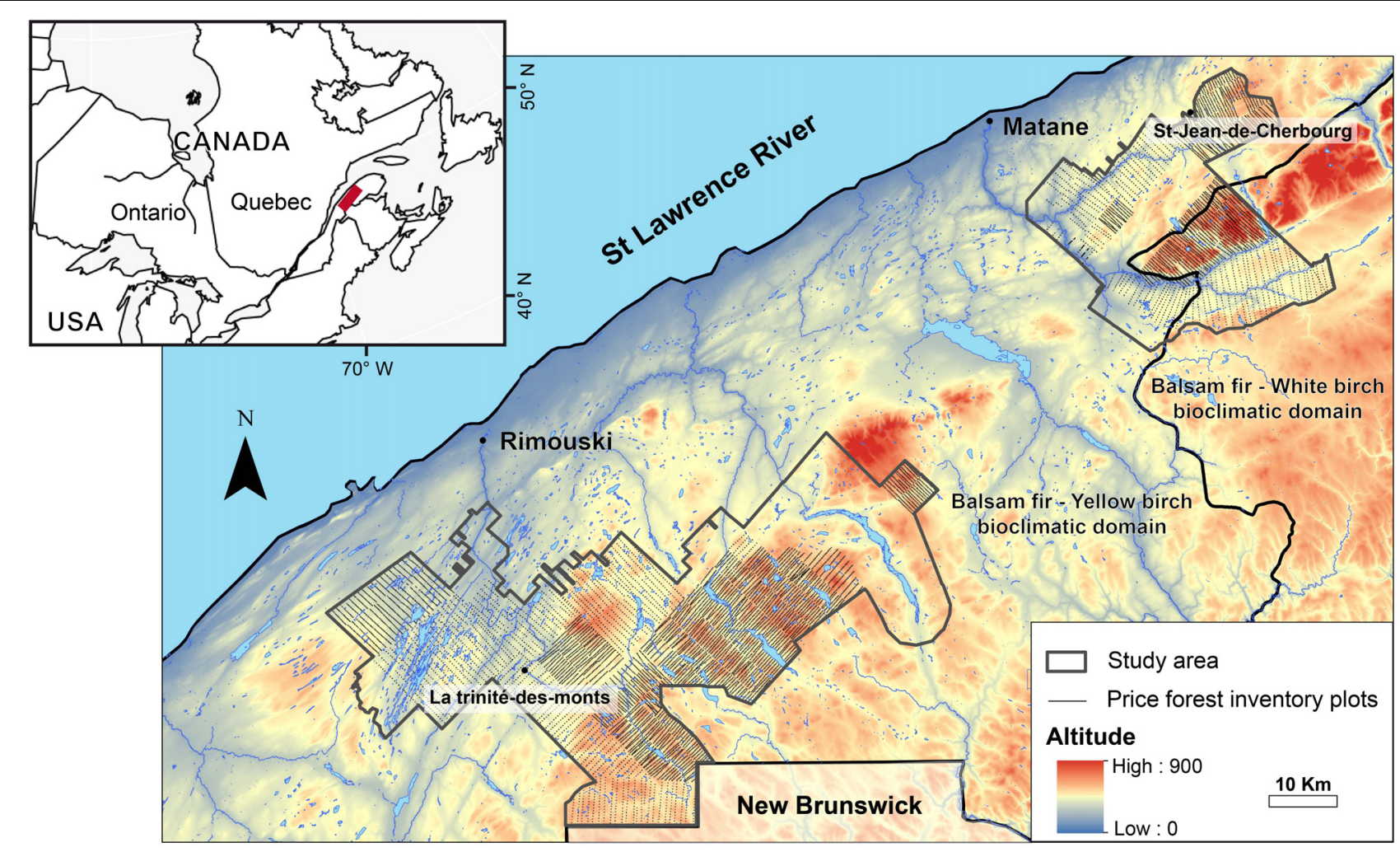

FIGURE 1 | Location of the Rimouski and Matane sectors and distribution of Price forest inventory plots in eastern Canada.

and balsam fir ( $>3$ inches DBH). This phase was also marked by the progressive introduction of chainsaws and log transport by trucks (Fortin et al., 1993). In the 1970s, dramatic changes occurred over the landscape, due to mechanization and the increased cutting rate in the snow-free season (Boucher et al., 2009a). Meanwhile, a severe spruce budworm outbreak (SBW) (Choristoneura fumiferana) between 1975 and1992 (Boulanger and Arseneault, 2004) triggered extensive salvage logging and consecutive large scale spruce plantations (Fortin et al., 1993). To our knowledge, there is no documentation of pre-European anthropogenic disturbances in the LSL region. Nevertheless, Aboriginal influence in modifying the natural fire regime has been documented elsewhere in eastern North America (Williams, 2000; Blarquez et al., 2018), and could have participated in influencing pre-industrial forest composition.

\section{Sources and Types of Maps Data}

We digitized and georeferenced maps from several sources (Table 1). In their study, Boucher et al. (2009b) digitized and analyzed maps produced during an exhaustive 1930 forest inventory by the Price Brother's \& Company. Along with these data, in the present study we discovered maps of a significant extension of the 1930 inventory and digitized stand age as well as all disturbance polygons. We also georeferenced and digitized 61 maps of the Price archive fund showing logged areas, logging previsions and fire polygons for different sections of the Rimouski and Matane sectors. These historical maps were georeferenced using lakes and confined rivers from Quebec ministry of natural resources' modern maps (MFWP). In addition, we used a map of the LSL region made from a 1938 aerial survey showing fires of the $\sim 1900-1938$ period (Hébert, 1938). This map was previously analyzed by Terrail (2013). Our database also included more recent fire polygons obtained as shapefiles from the fire protection agency in Quebec (SOPFEU). Finally, we used the four decadal forest inventory maps produced by the Quebec's ministry of Forests, Wildlife and Parks (MFWP) from ground surveys and aerial photographs taken in 1973-1974, 1985-1986, 1993, and 2004, respectively. We digitized disturbance polygons for the first and second decadal inventory maps, while the third and fourth decadal maps were directly obtained as digitized polygons by the MFWP.

Creating a homogenous database of all disturbance polygons was somewhat challenging, mostly due to the variable resolution of maps and the occasional repetition of some polygons in different data sources, sometimes with different dates. When a same polygon was repeated on two maps with a spatial mismatch, both polygons were merged. When dates were inconsistent for a same polygon on two different maps, the oldest date was kept, as it indicates the first mention of the occurrence of the disturbance polygon. On the maps, logging polygons between 1895 and 1965 were identified as Cut Over zones, without a precise logging type. However, these cut over zones were most likely diameter limit selective logging operations, based on written accounts of logging practices at that time 
(Price Brothers and Company Limited, 1944; Fortin et al., 1993) as well as an analysis of forest diameter structure in survey plots in 1930-1931 of logged areas against unlogged forest (see Appendix 1 and 2). Logging polygons for the period 19652005 were classified as partial cuts (25-75\% basal area removal) or total cuts (more than $75 \%$ basal area removal) based on Quebec's department of forests decadal inventories. The 1970s SBW severity was equally categorized by Quebec's department of forests into moderate outbreaks (between 25 and $75 \%$ defoliation) and severe outbreaks (more than $75 \%$ defoliation).

The four main disturbance categories that have been considered in our analyses are (1) fire (1895-2005), (2) logging (1895-2005), (3) plantations (1955-2005), and (4) SBW (19752005). Although the natural or anthropogenic origin of fires is not directly known, their spatial pattern indicates a predominant anthropogenic origin (Terrail, 2013). In addition, even if a plantation is not a disturbance per se, plantations were included in our analysis as a human-imposed forest recovery pattern that caused important compositional difference compared to naturally regenerated stands.

The SBW of 1975-1992 and windthrows are considered natural disturbances in our database for which we have spatial information. Two additional outbreaks occurred in the region during the 20th century in 1947-1958 and 1914-1923 (Boulanger and Arseneault, 2004) for which we have no spatial information. Hence, the impact of SBWs during the 20th century might be under-estimated in our database. It is also important to note that SBWs might be indirectly influenced by human activity through climate change (Gray, 2008). Yet, we included the spatial data we have of the 1970s SBW to compare its extent and rotation period and to examine its interactions with previous and subsequent anthropogenic disturbances. Areas impacted by windthrows are negligible in extent compared to other disturbances and are only included for descriptive purposes of the disturbance regime. For each disturbance type, we estimated affected area $\left(\mathrm{km}^{2}\right.$ and \% of the study area), rate (\% of the study area /year) and rotation period (i.e., the time necessary for a disturbance to cover an area equivalent to the study area; Frelich, 2002). We also calculated the affected area disturbed per decade and the cumulative area disturbed for the four main disturbance types.

\section{Sources and Types of Sampling Plots Data}

We assessed tree composition in 1930-1931 and in 1985-2005. For the 1930-1931 period, we used a detailed forest inventory conducted by the Price Brothers \& Company in a total of 16 345 rectangular plots $(10 \times 100 \mathrm{~m})$ of 0.1 ha each, systematically distributed across the Rimouski and Matane sectors (Figure 1). Tree taxa ( $>3$ inches; $\sim 7.6 \mathrm{~cm}$ ) were then tallied by 2 inches DBH classes. We georeferenced plots from their location on a 1930 map at the scale of 1: 16000. Some taxa in the historical forest inventory were grouped at the genus level: Maples (Acer spp.), Spruces (Picea spp.), Pines (Pinus spp.), and Poplars. Other taxa were identified at the species level: balsam fir, yellow birch, white birch, northern white cedar, black ash (Fraxinus nigra), American larch (Larix laricina), and American elm (Ulmus
Americana). Similarly, present-day forest composition (19852005) was described from the sampling plots of the second, third and fourth decadal forest inventories (1985-1986, 1993, and 2004) conducted by the MFWP. The first inventory was excluded because plot location is not georeferenced. During these inventories, circular sampling plots of 0.04 ha were randomly stratified according to forest stand type, excluding non-forested, unproductive and inaccessible (slope $>40 \%$ ) stands. Within plots, tree taxa were tallied by $2 \mathrm{~cm} \mathrm{DBH}$ classes, although DBH classes $<8 \mathrm{~cm}$ were excluded to match the 1930 plot database. We grouped the diametral structure (Density of stems / $10 \mathrm{~cm}$ diameter class) for each time period. Plots of the 19852005 time period were separated into two categories: naturally regenerated stands and plantations. We divided the study area into 333 grid cells of $3 \mathrm{~km}$ by $3 \mathrm{~km}$. The cells contained at least four (4) inventory plots per period. We calculated the mean basal area per taxa for redundancy analysis (RDA). The study area division in $3 \mathrm{~km}$ by $3 \mathrm{~km}$ grid cells should attenuate the bias associated with the uncertainty of historical inventory sampling plots position and the variable resolution of maps used to reconstruct disturbance history. The historical inventory sampling plots position uncertainty range from 0 to $340 \mathrm{~m}$ and the resolution of maps used range from 1: 16000 to 1 : 190000 (Table 1).

\section{Redundancy Analysis}

Two redundancy analyses (RDA) were performed. First, we used RDA in order to examine the effect of environment and vegetation composition in 1930-1931 on subsequent occurrence of disturbances. Second, we performed a partial RDA after controlling for environment and pre-industrial vegetation in order to examine the influence of disturbances on present-day forest composition. A grid of 333 cells of $3 \mathrm{~km}$ by $3 \mathrm{~km}$ covering the study area was generated to calculate, within each cell, disturbance cover percentage, environmental variables and basal area of tree taxa in 1930-1931 and 1985-2005. We calculated the cover percentage of Fire (1895-2005), Cut Over (18951935), Cut Over (1935-1965), Partial Cut (1965-2005), Total Cut (1965-2005), Plantations (1955-2005), and SBW (1975-2005). For environmental variables (Table 2), we used the mean value of 10 random points per grid cell to calculate altitude $(\mathrm{m})$, slope $\left({ }^{\circ}\right)$, aspect $\left({ }^{\circ}\right)$, closest distance from main rivers $(\mathrm{m})$, closest distance from secondary rivers and lakes $(\mathrm{m})$, and closest distance from private lands $(\mathrm{m})$. Cells located inside private lands have a distance of $0 \mathrm{~m}$. We also calculated soil deposit types and drainage classes cover per cell. For the two RDAs, we selected only significant variables using forward selection with the package vegan in $\mathrm{R}$ (Tables 4, 5). Disturbances, taxa basal area of 19301931 and 1985-2005 variables were Hellinger transformed while environmental variables were standardized to zero mean and unit variance. The variation explained was reported using the adjusted $R 2$, which takes the number of predictor variables and sample size into account to prevent the inflation of $R 2$ values. A permutation test was applied to test for the significance of the models and axes. Partial RDAs were also performed to calculate the individual adjusted $R 2$ for each variable in environmental and forest composition of 1930-1931 and 1985-2005 datasets. 
TABLE 1 | Historical maps of disturbance polygons in the study area.

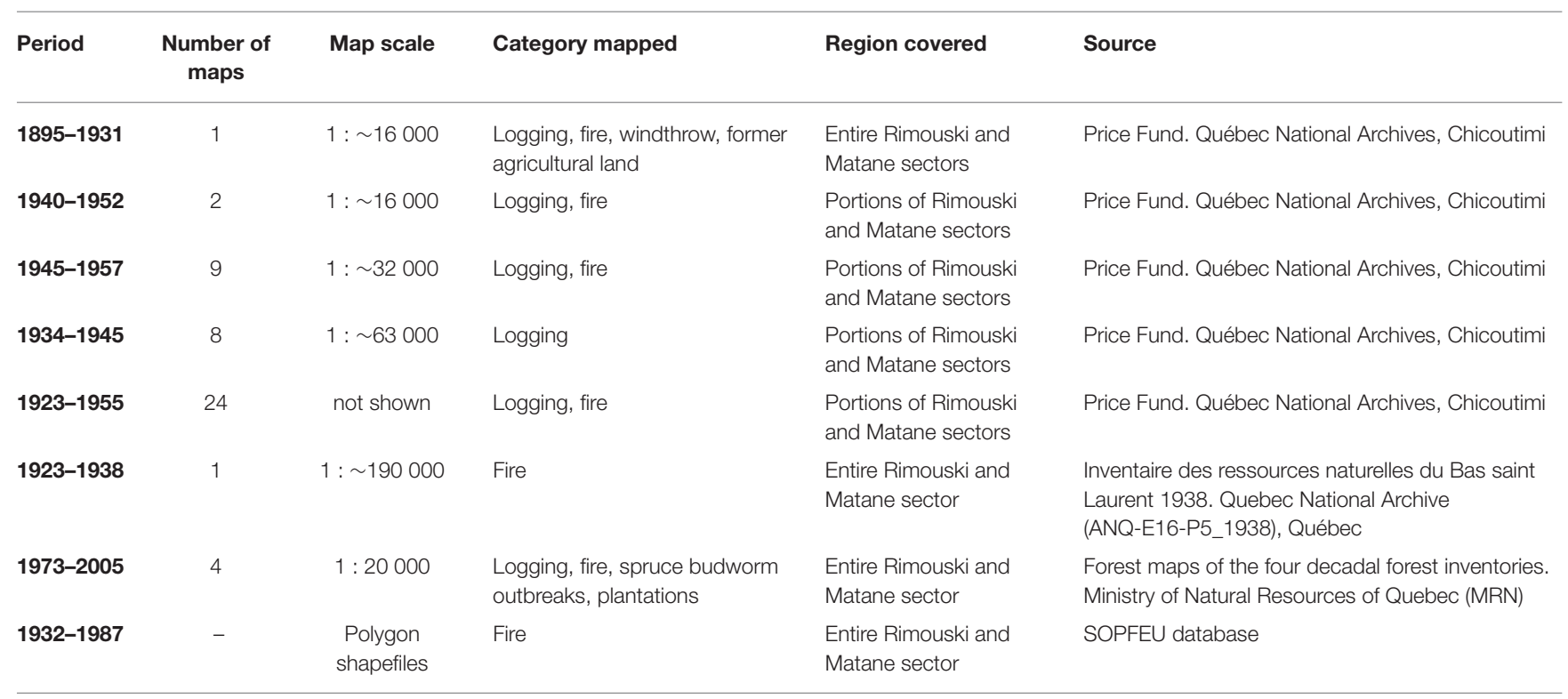

TABLE 2 | Environmental variables used in the RDA analysis.

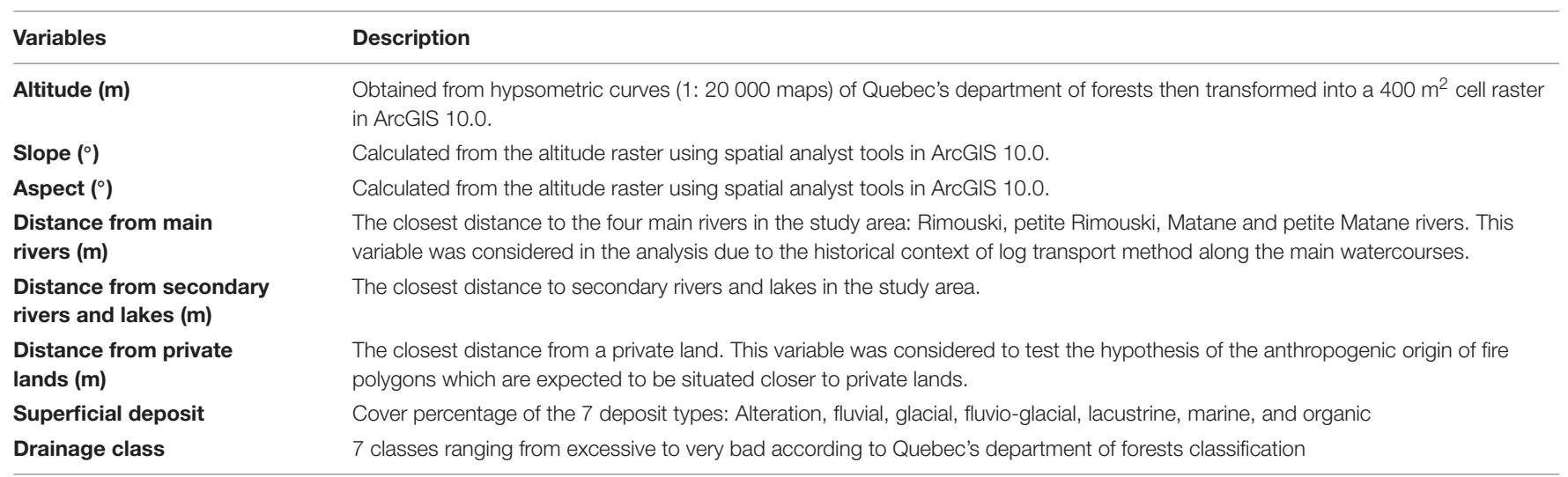

TABLE 3 | Parameters of the 20th century disturbance regime in the study area.

\begin{tabular}{|c|c|c|c|c|c|c|}
\hline \multirow[t]{4}{*}{ Fire } & 1895-2005 & 110 & 596 & 19 & 0.2 & 594 \\
\hline & 1895-1925 & 30 & 58 & 2 & 0.06 & 1668 \\
\hline & 1925-1955 & 30 & 483 & 15 & 0.50 & 200 \\
\hline & $1955-2005$ & 50 & 55 & 2 & 0.04 & 2925 \\
\hline \multirow{3}{*}{ Logging } & 1895-1935 & 40 & 844 & 26 & 0.7 & 152 \\
\hline & $1935-1965$ & 30 & 1219 & 38 & 1.3 & 79 \\
\hline & 1965-2005 & 40 & 2750 & 80 & 2 & 47 \\
\hline Plantations & 1955-2005 & 50 & 571 & 18 & 0.4 & 282 \\
\hline Spruce budworm & 1975-2005 & 30 & 1019 & 32 & 1.1 & 95 \\
\hline
\end{tabular}


TABLE 4 | Environmental and 1930-1931 basal area variables retained by forward selection in the RDA model to explain the 20th century disturbances.

\begin{tabular}{|c|c|c|c|c|c|}
\hline Variable & Acronym & Individual adjusted $R^{2}$ & Cumulated adjusted $R^{2}$ & $p$-value & Within group selection order \\
\hline \multicolumn{6}{|l|}{ Environmental variables } \\
\hline Distance from main rivers & Main Rivers & 0.084 & 0.088 & $\leq 0.001$ & 1 \\
\hline Distance from private lands & $\mathrm{PR}$ & 0.067 & 0.164 & $\leq 0.001$ & 2 \\
\hline Weathering deposit & Wthr & 0.013 & 0.204 & $\leq 0.001$ & 3 \\
\hline Distance from closest water course & Water & 0.007 & 0.220 & $\leq 0.001$ & 4 \\
\hline Glacial deposit & Glac & 0.012 & 0.233 & $\leq 0.001$ & 5 \\
\hline Fluvial deposit & Fluv & 0.004 & 0.240 & $<0.01$ & 6 \\
\hline Slope & Slope & 0.009 & 0.246 & $<0.01$ & 7 \\
\hline Altitude & Alt & 0.007 & 0.253 & $<0.01$ & 8 \\
\hline Aspect & - & - & - & $>0.05$ & - \\
\hline Drainage & - & - & - & $>0.05$ & - \\
\hline Fluvio-glacier deposit & - & - & - & $>0.05$ & - \\
\hline Lacustrine deposit & - & - & - & $>0.05$ & - \\
\hline Marine deposit & - & - & - & $>0.05$ & - \\
\hline Organic deposit & - & - & - & $>0.05$ & - \\
\hline \multicolumn{6}{|l|}{ Taxa basal area 1930} \\
\hline Picea spp. & Pic30 & 0.076 & 0.079 & $\leq 0.001$ & 1 \\
\hline Thuja occidentalis & Tho30 & 0.001 & 0.101 & $\leq 0.001$ & 2 \\
\hline Betula alleghaniensis & Bea30 & 0.030 & 0.117 & $\leq 0.001$ & 3 \\
\hline Pinus spp. & Pin30 & 0.017 & 0.128 & $<0.01$ & 4 \\
\hline Abies balsamea & Abb30 & 0.018 & 0.139 & $<0.01$ & 5 \\
\hline Betula papyrifera & Bep30 & 0.014 & 0.146 & $<0.01$ & 6 \\
\hline Fraxinus spp. & Frx30 & 0.006 & 0.151 & $<0.05$ & 7 \\
\hline Ulmus spp. & Ulm30 & 0.009 & 0.156 & $<0.05$ & 8 \\
\hline Acer spp. & Ace30 & 0.005 & 0.161 & $<0.05$ & 9 \\
\hline Larix laricina & - & - & - & $>0.05$ & - \\
\hline Populus spp. & - & - & - & $>0.05$ & - \\
\hline
\end{tabular}

Gray colored variables are not significant.

TABLE 5 | Disturbance variables retained by forward selection in the RDA model to explain taxa basal area in 1985-2005.

\begin{tabular}{|c|c|c|c|c|c|}
\hline Disturbance variables & Acronym & Individual adjusted $R^{2}$ & Cumulated adjusted $R^{2}$ & $p$-value & Within group selection order \\
\hline Partial cut (1965-2005) & CP05 & 0.021 & 0.021 & $\leq 0.001$ & 1 \\
\hline Fire (1895-2005) & FIRE & 0.014 & 0.035 & $\leq 0.001$ & 2 \\
\hline Plantations (1955-2005) & $\mathrm{PL}$ & 0.011 & 0.046 & $\leq 0.001$ & 3 \\
\hline Spruce Budworm outbreak (1975-2005) & SBW & 0.008 & 0.051 & $\leq 0.001$ & 4 \\
\hline Partial cut (1935-1965) & CO65 & 0.005 & 0.055 & $\leq 0.001$ & 5 \\
\hline Clear cut (1965-2005) & СТ05 & 0.005 & 0.059 & $\leq 0.001$ & 6 \\
\hline Partial cut (1895-1935) & $\mathrm{CO} 35$ & - & - & $>0.05$ & - \\
\hline
\end{tabular}

Gray colored variables are not significant.

These analyses were performed using the $\mathrm{R}$ 3.0.3. software (R Development Core Team, 2016).

\section{RESULTS}

\section{Description of the 20th Century Disturbance Regime}

During the 20th century, logging was the most widespread disturbance type, followed by fire, the 1970s SBW and plantations. Windthrows were negligible compared to other considered disturbances, with a rotation period of 3000 years
(Table 3 and Figures 2, 3). The cumulative area logged between 1895 and 2005 attained 144\% of the study area (Figure 4B). This indicates the some zones were logged more than once over the last 110 years. In total, $84 \%$ of the study area has been subjected to partial and/or total cut: $39 \%$ has been logged once, $34 \%$ twice, $10 \%$ thrice, and $1 \%$ logged four times. $16 \%$ of the study area has not been logged in our database. Approximately a third of the non-logged area has burned during the last century (Figure 2D). The unlogged, unburned area might have been subjected to non-documented anthropogenic disturbances absent from our data base, is located in inaccessible areas for logging, or reflects the bias associated to maps variable scales in our database. 


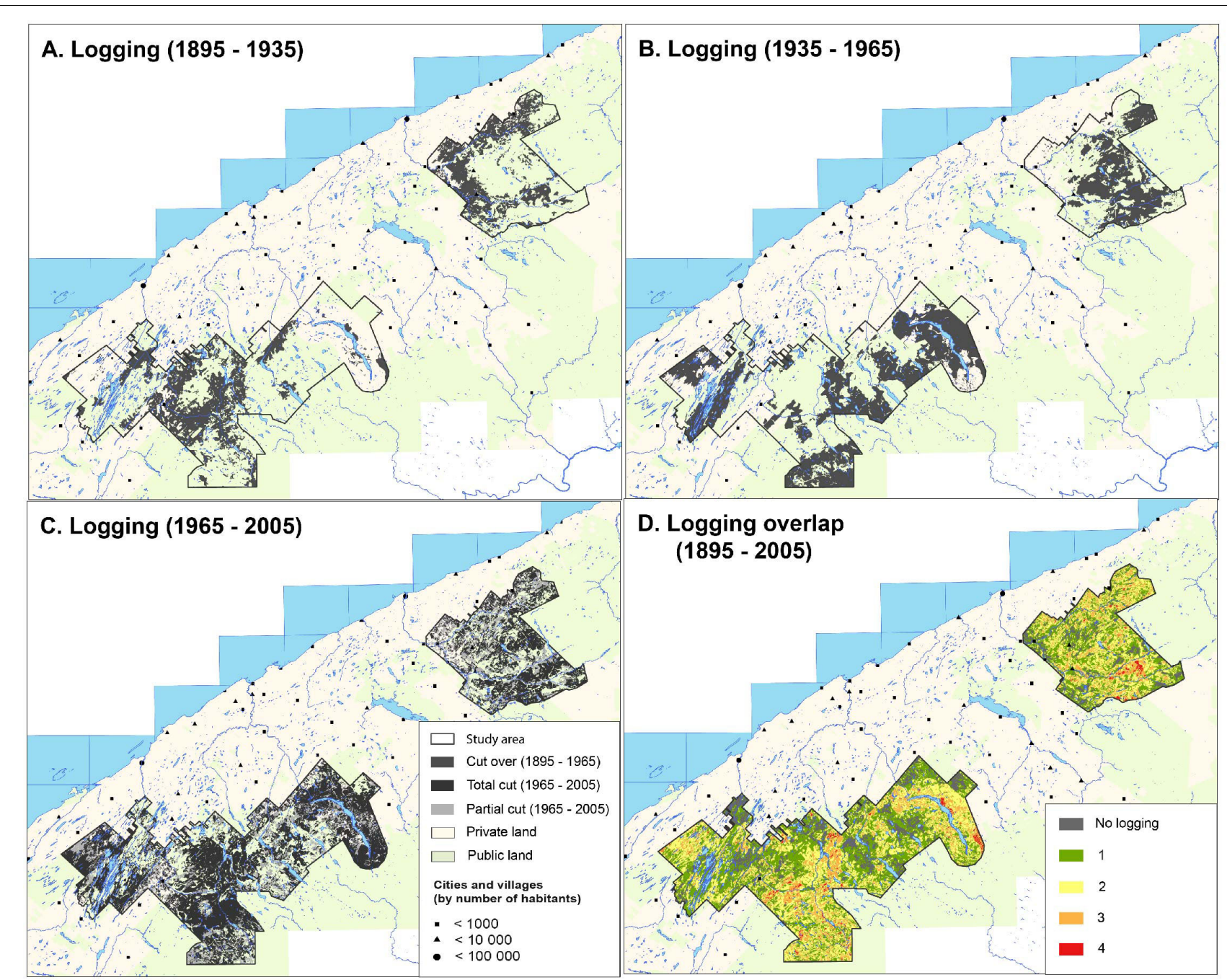

FIGURE 2 | Logged areas during the periods 1895-1935 (A), 1935-1965 (B), and 1965-2005 (C); (D) number of times each patch has been logged over the 1895-2005 study period.

Logging rotation period in the study area between 1895 and 2005 corresponds to 76 years. However, logging rotation period has continuously shortened throughout the 20th century, due to increasing industrial capacity, from 152 years in 1895-1935, to 79 years in 1935-1965, and 47 years in 1965-2005 (Table 3). Fire events were clustered around 1925-1955 (Figure 4A), in conjunction with the population increased in the study region (Figure 4E). Between 1895 and 2005, fires burned 19\% of the study area (Figure 4A), corresponding to a rotation period of 594 years. The fire rotation period decreased from 1668 years in 1895-1925 to 200 years in 1925-1955. Following the peak of settlement in the late 1950s, the fire rotation period increased to 2925 years (Table 3). Large scale plantations are relatively recent in the region and have covered $17.8 \%$ of the study area between 1955 and 2005 with a peak of $362 \mathrm{~km}^{2}$ between 1985 and 1995 (Figure 4C). SBW data are available only for the recent time (1965-2005) and show a peak of $486 \mathrm{~km}^{2}$ area affected between 1974 and 1986. The total area affected by the outbreak is $31.7 \%$ (Figure $4 \mathrm{D}$ ) corresponding to a rotation period of 95 years (Table 3 ).

\section{Spatial Structure of Anthropogenic Disturbances}

The RDA model indicates that the anthropogenic disturbances regime of the 20th century has been spatially structured by environmental variables and by the 1930-1931 tree composition (Adjusted $R 2=32 \%$; Figure 5). This structure reflects human settlement and land-use history during the 20th century. The first RDA axis (20\% of constrained variance) mostly expresses increasing distance from main rivers to the left (Individual R2adj $=0.084$; Table 4) as well as the basal area of spruces in 1930 (Pic30; Individual R2adj = 0.076). The second axis (6\% of constrained variance) shows a gradient from high Pines basal area in 1930 (Pin30, Individual $R 2 \mathrm{adj}=0.017$ ), steep slope (Individual R2adj $=0.009$ ) and weathering deposit (Individual R2adj $=0.013$ ) up to Glacial deposit (Individual 


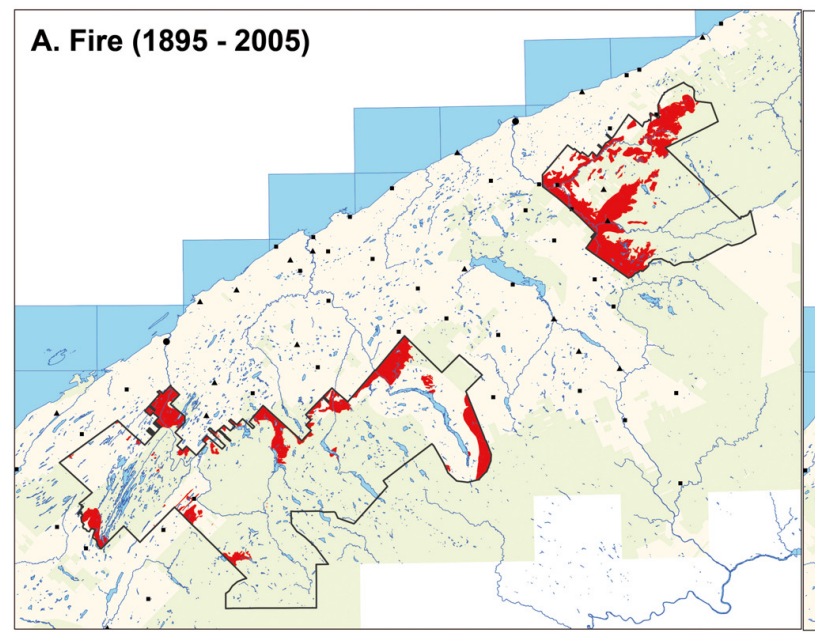

\section{Spruce budworm outbreaks (1975 - 2005)}

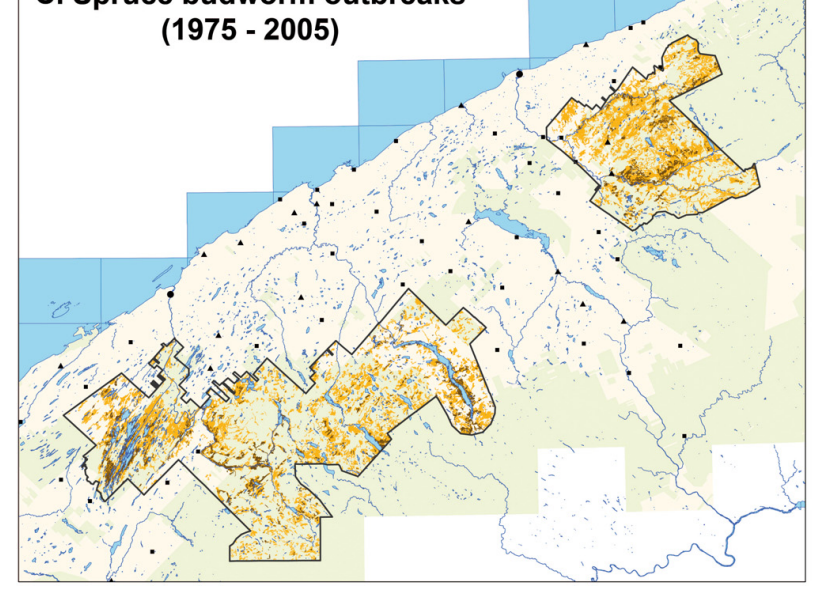

B. Plantations (1955 - 2005)

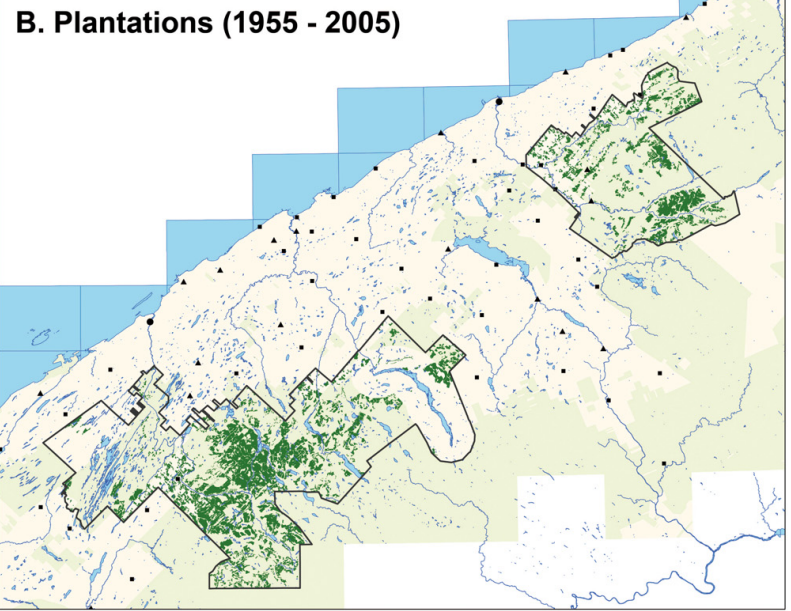

Study Area

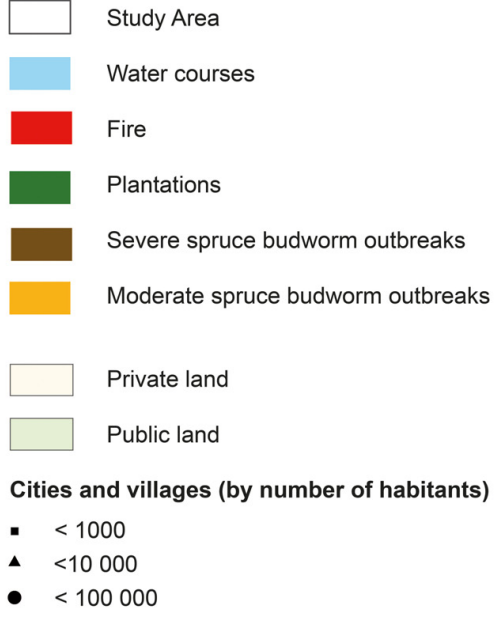

FIGURE 3 | Maps of fires (A), plantations (B), and spruce budworm outbreaks (C) disturbances in the Rimouski and Matane sectors.

R2adj $=0.012$ ) and high birch basal area in 1930 (Bea30 and Bep30, respectively, with Individual $R 2 \mathrm{adj}=0.030$ and 0.014 ). Distance from private lands (PR; Individual $R 2 \mathrm{adj}=0.067)$ and altitude (alt, Individual $R 2 \mathrm{adj}=0.007$ ) are explained by both the first and second axis of the RDA. Cut over zones between 1895 and 1935 (CO35) are situated next to main rivers. Between 1935 and 1965, logging activities (CO65) moved away from main rivers (situated in the opposite direction of CO35 in the multivariate space) toward areas where spruces were still abundant. Between 1965 and 2005 logged areas (CP05 and CT05) became diffuse across the study region and showed no specific spatial location in the multivariate space. Plantations (1955-2005; $\mathrm{PL}$ ) occurred in flat zones, while SBW is observed in steep zones. Finally, fires (1895-2005) occurred in low altitude areas close to private lands.

\section{Modern Taxa Composition and Diameter Structure}

According to the partial RDA, the 20th century disturbance regime explained $6 \%$ of the modern basal area (1985-2005) in the landscape (Figure 6). The first RDA axis mostly express a gradient of partial cut (1965-2005) (CP05; Individual $R 2 \mathrm{adj}=0.021$; Table 5) while the second axis shows a gradient from fire (FIRE; Individual $R 2 \mathrm{adj}=0.014$ ) to spruce budworm outbreak (SBW; Individual $R 2 \mathrm{adj}=0.008)$. The third axis shows a gradient of plantation $(\mathrm{PL}$; Individual $R 2 \mathrm{adj}=0.011)$. Partial cuts between 1965 and 2005, fires and plantations explain 4.6\% out of the 6\% of the variance among disturbance variables. Trembling aspen (Pot) is correlated to burned areas. Sugar maple (Acs) and yellow birch (Bea) are correlated to partial cuts between 1965 and 2005. Black spruce (Pim) is associated with plantations. Northern white cedar (Tho) is not explained by any studied disturbance type as it is perpendicular to all disturbances in the multivariate space.

Between historical (1930-1931) and present-day (1985-2005) periods, we observed a change in basal area and diameter structure of tree taxa. Total basal area increased noticeably by $5.1 \mathrm{~m}^{2} /$ ha in naturally regenerating stands, while it decreased by $2.8 \mathrm{~m}^{2} /$ ha in plantations (Table 6). Most plantations were likely thinned at the time of sampling. The increase in basal area in naturally regenerating stands is largely due to a threefold increase 


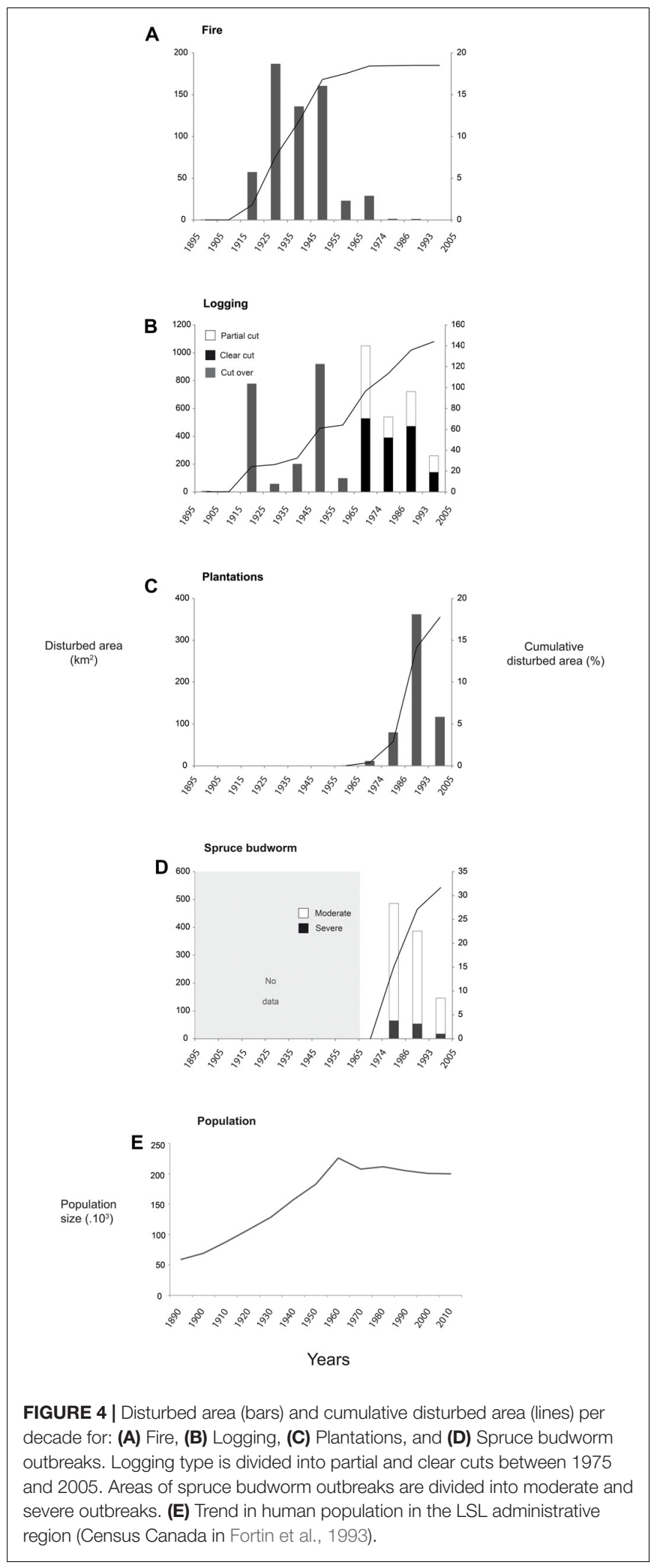

of northern white cedar by $2.7 \mathrm{~m}^{2} / \mathrm{ha}$ and a nine fold increase in maples by $1.5 \mathrm{~m}^{2} / \mathrm{ha}$. This increase was accompanied by an increase in the density of northern white cedar in all diameter classes and an increase in maples density for small diameter classes (Figures 7, 8). A slight increase in basal area for spruces, balsam fir and poplars and a decrease in yellow birch and white birch also occurred (Figure 8), although an increased density of stems in small diameter classes occurred for these species in naturally regenerated stands (Figure 7). In plantations, $41 \%$ $\left(7.1 \mathrm{~m}^{2} / \mathrm{ha}\right)$ of the mean basal area is represented by Spruces (Table 6) with a significant increase in stem density in the smallest diameter class for this taxa compared to historical and modern naturally regenerated stands values (Figure 7). The mean basal area of secondary natural regeneration of balsam fir (fir has not been planted) in plantations represent $44 \%\left(7.6 \mathrm{~m}^{2} / \mathrm{ha}\right)$. Balsam fir density has slightly increased in the smallest diameter class compared to historical and modern naturally regenerated stands values (Figure 7).

\section{DISCUSSION}

\section{Anthropogenic Disturbance Regime of the 20th Century}

During the 20th century, anthropogenic disturbances were omnipresent in the landscape, as for other regions of the eastern North American mixed forests (Foster, 1992; Whitney, 1994; Friedman and Reich, 2005). Fire activity was concentrated at low elevation during the settlement period, close to private lands suggesting ignitions from anthropogenic origins (Figures 3A, 5). Logging activities expanded from around main rivers during the first half of the 20th century toward inland areas and higher altitude by the second half of the century (Figures 2, 5), marking the transition from log transport by watercourses to the use of forest roads and trucks. Moreover, $18 \%$ of these logged zones have been subsequently transformed into plantations, mostly between 1985 and 1995, during the last SBW (1975-1990). Planted zones were chosen in backcountry accessible sectors and mostly planted with insect resistant black spruce (Pim), while the less accessible sectors on steeper slopes were disturbed by the SBW outbreak (Figures 5, 6).

Before European settlement, the pre-industrial disturbance regime of south-eastern Quebec and northern New England was dominated by secondary disturbances like windthrows and insect outbreaks (Blais, 1961; Lorimer, 1977; Bormann and Likens, 1979; Payette et al., 1990; Frelich, 2002; Lorimer and White, 2003). For the LSL region, this can be inferred from the oldgrowth, uneven aged forest structure of the pre-settlement forest, which was also dominated by fire-sensitive species (balsam fir, white spruce, eastern white cedar) (Etheridge et al., 2005; Boucher et al., 2009b; Dupuis et al., 2011). The very long rotation period we estimated for windthrows in the study area over the 20th century (about 3000 years; less than $1 \%$ of the landscape affected; Table 3) is considerably longer than the value of 1150 years estimated by Lorimer (1977) for Northern Maine between 1793 and 1827. This discrepancy may emphasize a relatively low occurrence of large windthrows in the study area. Indeed, wind storms that create large canopy openings are known to be infrequent in this type of mixed forests (Frelich and Lorimer, 1991; Lorimer and White, 2003). Nevertheless, windthrows could 


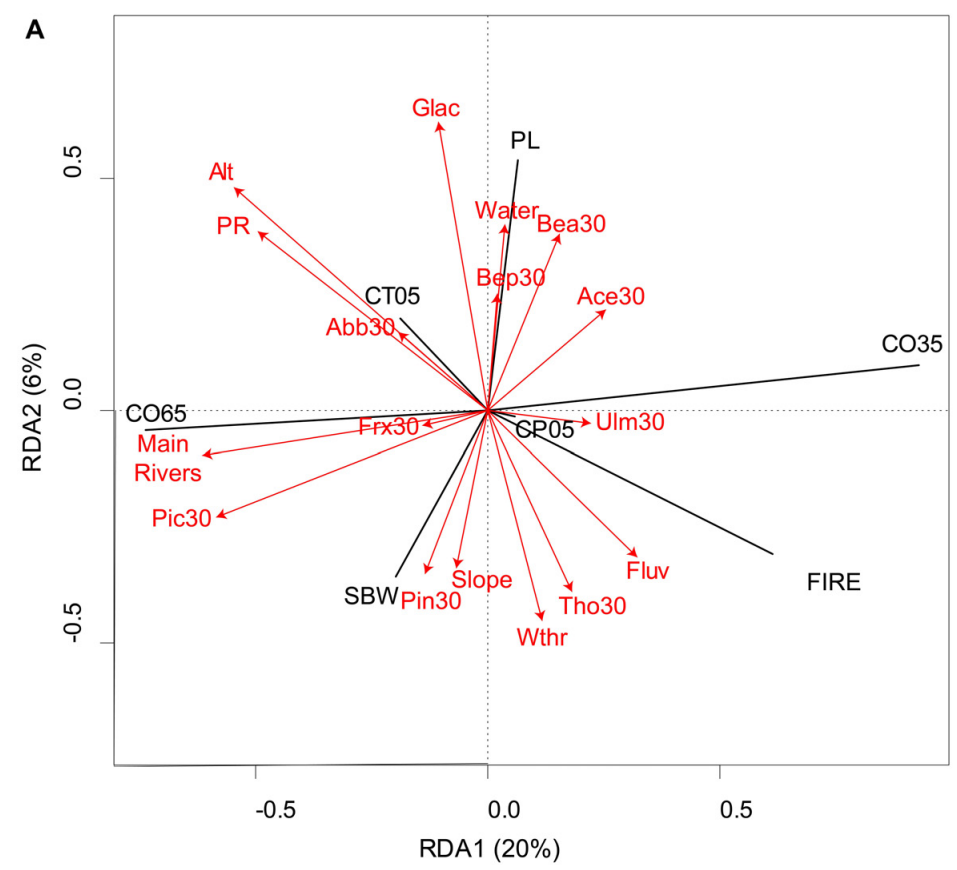

B

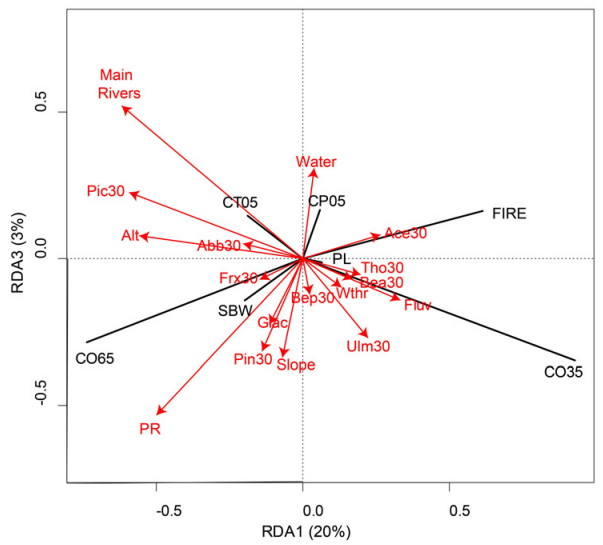

FIGURE 5 | Redundancy analysis (model adjusted R2 = 32\%) of the 20th century disturbances (black lines) correlated to 17 explanatory variables (red vectors) in two driver sets (environmental variables and taxa basal area in 1930). Projections showed using (A) first and second ordination axes, and (B) first and third ordination axes. $N=333$ cells of $3 \times 3$ km. FIRE: Fire (1895-2005), PL: Plantations (1955-2005), SBW: Spruce Budworm outbreaks (1975-2005), CO35: Cut over (1895-1935), CO65: Cut over (1935-1965), CP05: Partial cut (1965-2005), CT05: Clear cut (1965-2005). Acronyms of explanatory variables are indicated in the Table 4.
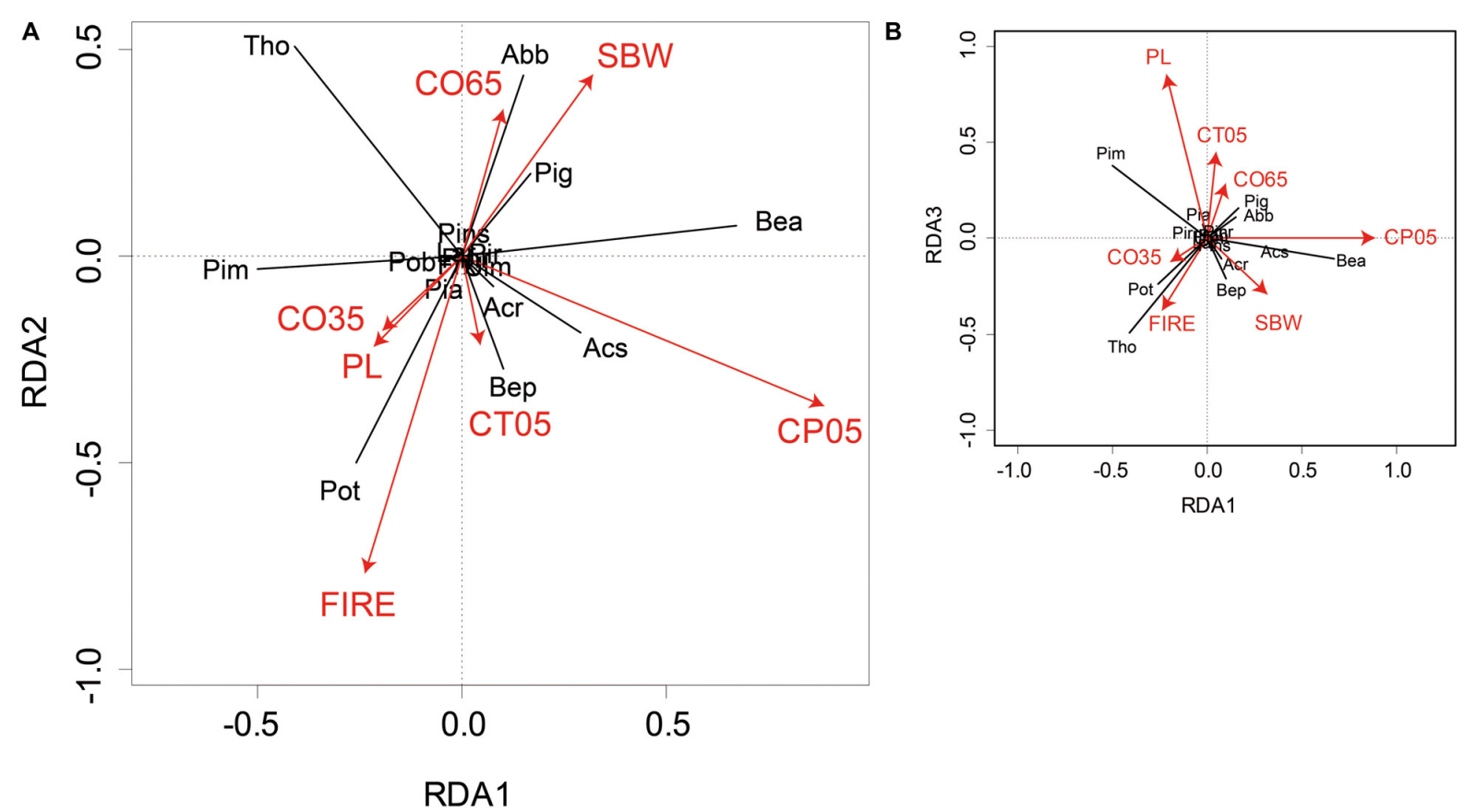

FIGURE 6 | Redundancy analysis (model Adjusted R2 = 6\%) of taxa basal area in 2005 (black lines) correlated to 7 disturbance explanatory variables (red vectors). Projections showed using (A) first and second ordination axes and (B) first and third ordination axes. $N=4573$ temporary plots of the 2nd, 3rd, and 4th government decennial inventories. Frx, Ash; Abb, Balsam fir; Tho, Northern white cedar; Ulm, American elm; Lar, American larch; Acr, Red maple; Acs, Sugar maple; Pob, Balsam poplar; Pot, Trembling aspen; Pins, White pine; Pinr, Red pine; Pim, Black spruce; Pia, Norway spruce; Pir, Red spruce; Pig, White spruce; Bea, Yellow birch; Bep, White birch. Acronyms of explanatory variables are indicated in the Table $\mathbf{5}$. 
TABLE 6 | Taxa basal area (m2/ha \pm sd) in 1930-1931 ( $N=16804)$ and 1985-2005 for the whole study area.

\begin{tabular}{|c|c|c|c|c|c|}
\hline \multirow{2}{*}{$\begin{array}{l}\text { Species } \\
\text { Common name }\end{array}$} & \multirow[t]{2}{*}{ Latin name } & \multirow[t]{2}{*}{ Acronym } & \multirow[t]{2}{*}{$1930-1931$} & \multicolumn{2}{|c|}{ 1985-2005 } \\
\hline & & & & Natural regeneration & Plantations \\
\hline Balsam fir & Abies balsamea & Abb & $9.2( \pm 6.3)$ & $9.8( \pm 9.2)$ & $7.6( \pm 8.7)$ \\
\hline American larch & Larix laricina & Lar & $0.01( \pm 0.3)$ & $0.06( \pm 0.62)$ & $0.00( \pm 0.07)$ \\
\hline Spruces & Picea spp. & Pic & $3.6( \pm 3.8)$ & $4.7( \pm 5.5)$ & $7.1( \pm 7.6)$ \\
\hline Norway spruce & Picea abies & Pia & - & $0.04( \pm 1.07)$ & $0.7( \pm 4.3)$ \\
\hline White spruce & Picea glauca & Pig & - & $3.3( \pm 4.3)$ & $3.2( \pm 5.2)$ \\
\hline Black spruce & Picea mariana & Pim & - & $1.2( \pm 3.9)$ & $3.0( \pm 5.9)$ \\
\hline Red spruce & Picea rubens & Pir & - & $0.1( \pm 0.9)$ & $0.2( \pm 1.5)$ \\
\hline Pines & Pinus spp. & Pin & $0.03( \pm 0.38)$ & $0.07( \pm 0.74)$ & $0.00( \pm 0.03)$ \\
\hline Red pine & Pinus resinosa & Pinr & - & $0.02( \pm 0.40)$ & $0.00( \pm 0.03)$ \\
\hline White pine & Pinus strobus & Pins & - & $0.05( \pm 0.61)$ & $0.00( \pm 0.00)$ \\
\hline Northern white cedar & Thuja occidentalis & Tho & $1.6( \pm 4.5)$ & $4.3( \pm 10.6)$ & $0.3( \pm 2.4)$ \\
\hline Conifer basal area & & - & $14.5( \pm 8.5)$ & $18.9( \pm 14.0)$ & $14.9( \pm 2.5)$ \\
\hline Maples & Acer spp. & Ace & $0.18( \pm 1.1)$ & $1.7( \pm 4.5)$ & $0.3( \pm 1.4)$ \\
\hline Red maple & Acer rubrum & Acr & - & $0.7( \pm 2.0)$ & $0.1( \pm 0.8)$ \\
\hline Sugar maple & Acer saccharum & Acs & - & $1.0( \pm 4.0)$ & $0.2(1.1)$ \\
\hline Yellow birch & Betula alleghaniensis & Bea & $1.8( \pm 3.2)$ & $1.7( \pm 3.3)$ & $0.7( \pm 2.0)$ \\
\hline White birch & Betula papyrifera & Bep & $3.6( \pm 3.5)$ & $2.3( \pm 0.2)$ & $1.0( \pm 1.9)$ \\
\hline Black ash & Fraxinus nigra & Frx & $0.02( \pm 0.3)$ & $0.04( \pm 0.43)$ & $0.00( \pm 0.01)$ \\
\hline Poplars & Populus spp. & Pop & $0.05( \pm 0.58)$ & $0.8( \pm 3.6)$ & $0.4( \pm 2.4)$ \\
\hline Balsam poplar & Populus balsamifera & Pob & - & $0.3( \pm 2.4)$ & $0.1( \pm 1.3)$ \\
\hline Trembling aspen & Populus tremuloides & Pot & - & $0.5( \pm 2.6)$ & $0.3( \pm 2.0)$ \\
\hline American elm & Ulmus americana & Ulm & $0.01( \pm 0.22)$ & 0 & 0 \\
\hline Deciduous basal area & & - & $5.7( \pm 5.0)$ & $6.4( \pm 7.2)$ & $2.5( \pm 4.3)$ \\
\hline Total & & - & $20.2( \pm 9.3)$ & $25.3( \pm 12.4)$ & $17.4( \pm 10.7)$ \\
\hline
\end{tabular}

Basal area for the 1985-2005 period is divided into two groups according to origin: natural regeneration $(N=3797)$ or plantation ( $N=385)$.

be more frequent with high harvesting intensity in partial cut stands (Montoro Girona et al., 2019). Although tree ring evidence indicate a time interval of 40 years between successive SBWs in the LSL region over the past 450 years (Boulanger and Arseneault, 2004), the rotation period for presettlement SBW $s$ is hard to calculate due to the lack of spatial data.

Escaped-settlement fires and extensive logging during the 20th century have strongly altered the type, rotation period, severity and extent of disturbance events (Table 3). Compared to a fire rotation period of 200 years at the peak of human settlement in the region (1925-1955), the value of 1668 years calculated for the 1895-1925 interval is closer to values suggested elsewhere for pre-industrial landscapes of the temperate zone. Natural fires were documented to be rare in the presettlement land surveys in the temperate forests of eastern North America (Siccama, 1971; Lorimer, 1977; Foster et al., 1998). For example, recently burned areas covered $10 \%$ of the landscape in Northern Maine shortly before settlement, with a rotation period estimated to be 800 years (Lorimer, 1977). An even longer fire rotation period of 1240 was reported for spruce-fir forests in Maine (Fahey and Reiners, 1981). At the same time logging evolved from partial cutting diameter-limit management, associated to the saw mill industry, at the beginning of the century to total cutting, associated to the pulp and paper industry, by the end of the century (Fortin et al., 1993; Boucher et al., 2009a,c). In the past decades, efforts for forest sustainable management suggested more partial cutting as an alternative to clearcutting in the province of Quebec and elsewhere in eastern North America (Landres et al., 1999; Harvey et al., 2002; Lindenmayer and Franklin, 2002). Overall, logging covered $144 \%$ of the study area between 1895 and 2005, with 45\% of the study area logged more than once.

\section{0th Century Anthropogenic Disturbances Impact on Present Day Forest Composition}

Mixed forests in our study area showed resilience in terms of composition, despite the omnipresence of anthropogenic disturbances during the 20th century. There is a correlation between tree taxa basal area in 1930-1931 and presentday taxa basal area (Figure 8). At the beginning of the century, diameter limit selective logging was conducted in winter and with minimal machinery (Fortin et al., 1993). This might have protected coniferous regeneration and limited the expansion of early successional deciduous tree species, contributing to the overall observed resilience of forests to logging operations at the beginning of the 20th century (Table 5). A study of Boucher et al. (2017) have used a similar database and disturbance data, as in this study, in the southern boreal forest of central Quebec, and have concluded that logging have a minor impact on compositional change. 


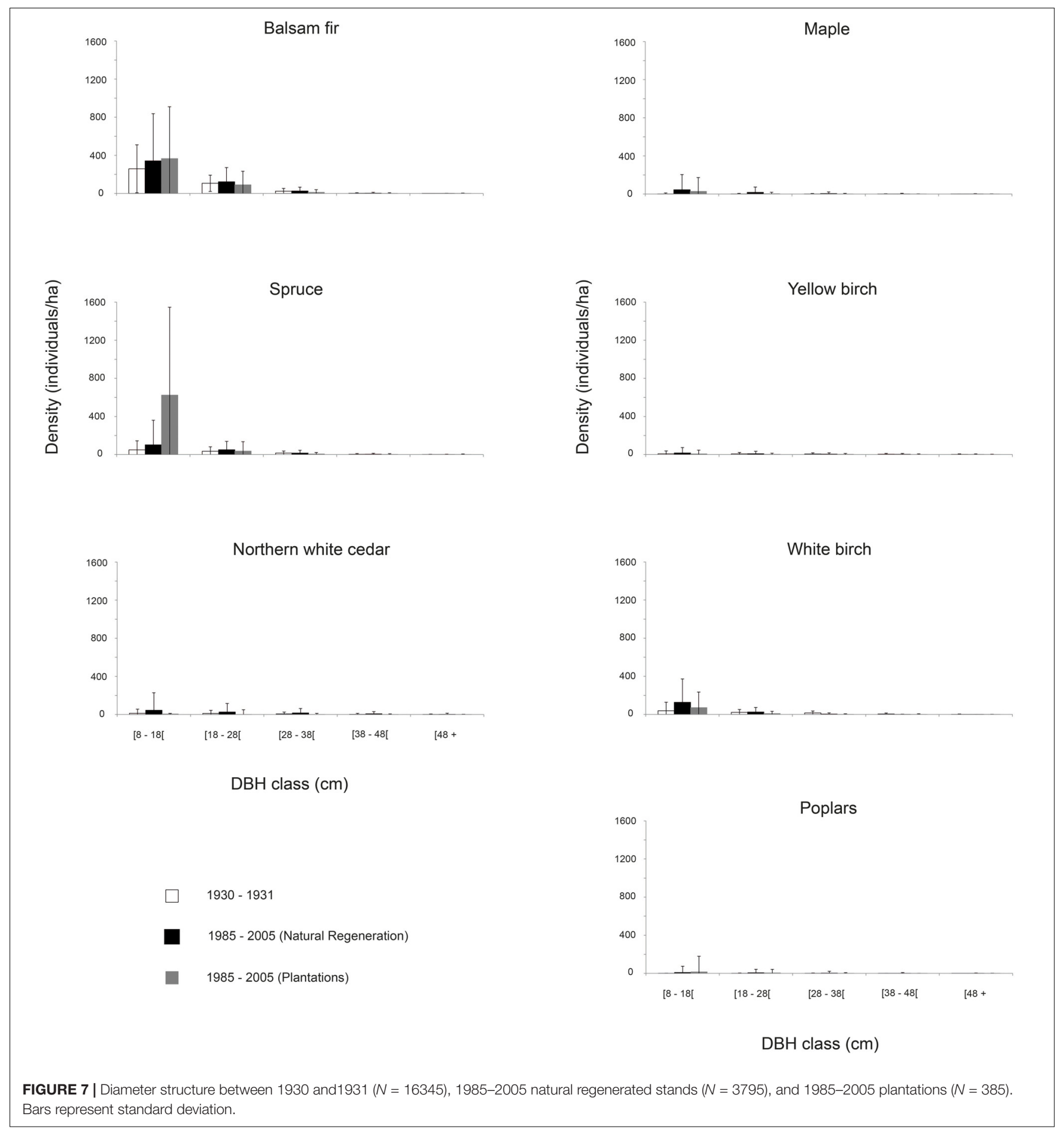

Disturbances of the 20th century explain only $6 \%$ of presentday tree composition (Figure 6), suggesting that they have not been an important agent of forest reorganization in our study area. This contrasts with more salient views in the literature which emphasize the impact of anthropogenic disturbances on forest composition (Whitney, 1994; Foster et al., 1998; Fuller et al., 1998; Friedman and Reich, 2005; Dupuis et al., 2011; Boucher et al., 2014; Fortin, 2018; Danneyrolles et al., 2019).
Many of these studies use vegetation data from historical land surveys (frequency of occurrence and dominance). The difference between our study area and other studies using historical land surveys might be that our study area is mostly located in public territory, while these studies were mostly located in private lands. More severe and frequent anthropogenic disturbances are likely to occur in private lands, as in the case of anthropogenic fires in our results (Figure 5). Moreover, the response of vegetation 


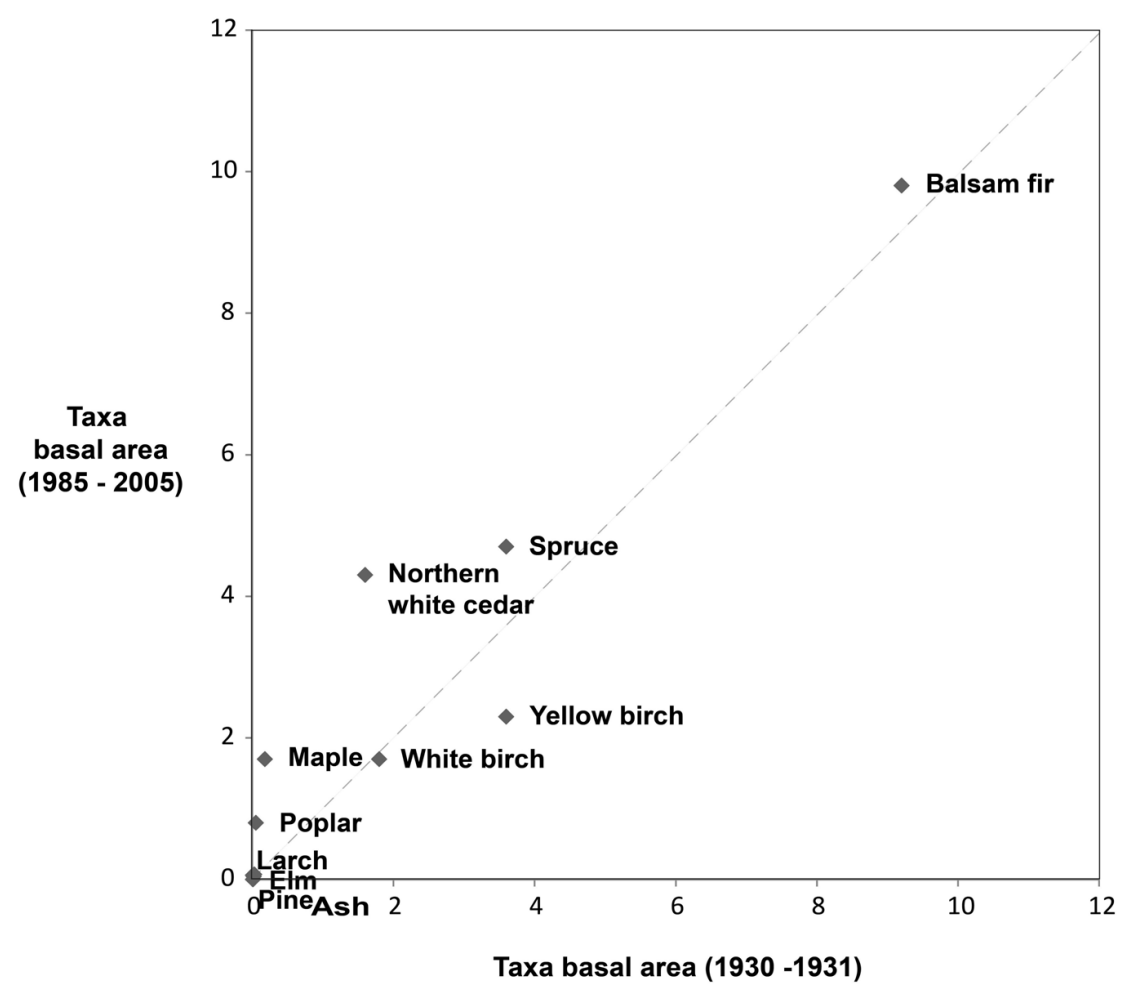

FIGURE 8 | Taxa basal area (m2.ha-1) in 1930-1931 and 1985-2005 in naturally regenerated stands.

to disturbances might be site specific and could have been attenuated by the use of a $9 \mathrm{~km}^{2}$ grid cells. The influence of total cuts on vegetation composition might not be fully ceased by our analysis (CT05 adj $R 2=0.005$; Table 5). Although naturally regenerated stands originating after total cuts between 1965 and 2005 cover $25 \%$ of the study area, many of the trees in these stands are 40 years old or younger and have smaller DBH than the $7 \mathrm{~cm}$ minimum DBH for trees measured in our database. Finally, the relatively short period of disturbance data availability (110 years) in this study and lacking data for some disturbance episodes (SBW) might have contributed in diminishing the effect of disturbances in present-day forest composition. Disturbances that have occurred long before our study might as well have a non-measured influence.

Despite the relatively low importance of disturbances to explain the present-day forest composition, some taxa responded to disturbances in an individualistic manner, reflecting their functional traits. The increase of early successional trembling aspen in naturally regenerated stands compared to the 19301931 time period (Figures 6-8 and Table 6) is correlated to the important increase in fire events. Several previous studies have linked the increase of trembling aspen with anthropogenic fires in eastern North America (Bergeron, 2000; Cleland et al., 2001; Friedman and Reich, 2005; Boucher et al., 2014, 2017; Terrail et al., 2019). We also found that the fire sensitive balsamfir (Rowe, 1972) is mostly abundant away from fire polygons (Figure 6). Species usually associated with gap dynamics, such as yellow birch and sugar maple, are correlated to partial cuts (1965-2005). These species might have benefited from the elimination of shade tolerant competitors in partial cuts as well as in areas impacted by SBW (Figure 6; Palik and Pregitzer, 1992; Abrams, 1998; Nie et al., 2018). Moreover, red and sugar maples produce a large quantity of seeds and can grow rapidly when exposed to light (Fei and Steiner, 2008; Nolet et al., 2008). In addition, management practices which aim at preserving yellow birch seed trees in logging operations might have favored the abundance of this species.

Planted areas have also participated to the observed presentday forest composition at the landscape level. They are human made ecosystems which are less diverse than naturally regenerated stands (Table 6), as $41 \%$ of plantations basal area is composed of spruces against $19 \%$ in natural regenerated stands (Table 6 and Figure 7). Other tree species found in planted stands consist in naturally regenerated balsam fir and early successional white birch.

Surprisingly northern white cedar, a late successional shade tolerant species increased in basal area and was not correlated to disturbances (Table 6 and Figure 6). This result is somewhat contrary to the general tendency of the decreased cedar abundance in eastern Canadian mixed forests, even though variable between regions (Danneyrolles et al., 2017). It's presentday increase and distribution in the landscape is probably better explained when environmental factors are considered. Northern white cedar is usually found in zones with poor drainage, organic deposit and in low altitude (Robitaille and Saucier, 1998). The study area's position in public territory might have also made northern white cedar exploitation less frequent. Yet, the interaction with partial natural and human disturbances (insect 
outbreaks and partial cuts) combined with an abundant advanced regeneration of northern white cedar was suggested to explain the dominance of this species (Heitzman et al., 1997; Ruel et al., 2014; Danneyrolles et al., 2017).

Determining the contribution of anthropogenic disturbances on forest composition should be studied along with other agents and their interactions at various spatial and temporal scales (Krankina et al., 2005; Gimmi et al., 2010; Landhäusser et al., 2010; Fisichelli et al., 2014; Nowacki and Abrams, 2015; Plieninger et al., 2016; Vayreda et al., 2016; Danneyrolles et al., 2019). For example, Boisvert-Marsh et al. (2019) have suggested that disturbance of the last 40 years have been less important than climate change to explain present-day forest composition, whereas Danneyrolles et al. (2019) concluded the contrary at the scale of the last century. Moreover, the characteristics of disturbances themselves (extent, frequency, intensity, type, return interval) and their combination might also have different influences on vegetation composition (Turner, 2010). In the present study, the conjugated analysis of disturbance history and associated compositional change over the transition period encompassing the early settlement of the population and the deployment of industrial forestry suggest moderate change in forest cover composition despite extensive anthropogenic disturbances in this representative eastern Canadian mixed forest.

Our study supports the recommendations of forest ecosystem management practices to use partial cutting to maintain the forest in its natural range of variability (Landres et al., 1999; Harvey et al., 2002; Lindenmayer and Franklin, 2002). On the other hand, further investigation is needed to study the impact of clear cutting as the length and data of our study don't permit the estimation of the impact of this stand replacing disturbance. Paleoecological

\section{REFERENCES}

Abrams, M. D. (1998). The red maple paradox: what explains the widespread expansion of red maple in eastern forests? Bioscience 48, 355-364. doi: 10.2307/ 1313374

Abrams, M. D. (2003). Where has all the white oak gone? Bioscience 53, 927-939. doi: 10.1641/0006-3568(2003)053[0927:WHATWO]2.0.CO;2

Bergeron, Y. (2000). Species and stand dynamics in the mixed woods of Quebec's southern boreal forest. Ecology 81, 1500-1516. doi: 10.1890/0012-9658(2000) 081[1500:SASDIT]2.0.CO;2

Blais, J. R. (1961). Spruce budworm outbreaks in the Lower St. Lawrence and Gaspé regions. For. Chron. 37, 192-202. doi: 10.5558/tfc37192-3

Blanchet, P. (2003). Feux de Forêt : L'hIstoire D'une Guerre. Montreal, QC: Trait d'union.

Blarquez, O., Talbot, J., Paillard, J., Lapointe-Elmrabti, L., Pelletier, N., and Gates St-Pierre, C. (2018). Late holocene influence of societies on the fire regime in southern Québec temperate forests. Quat. Sci. Rev. 180, 63-74. doi: 10.1016/j. quascirev.2017.11.022

Boisvert-Marsh, L., Périé, C., and de Blois, S. (2019). Divergent responses to climate change and disturbance drive recruitment patterns underlying latitudinal shifts of tree species. J. Ecol. 107, 1956-1969. doi: 10.1111/1365-2745. 13149

Bormann, F. H., and Likens, G. E. (1979). Catastrophic disturbance and the steady state in Northern hardwood forests: a new look at the role of disturbance in the development of forest ecosystems suggests important implications for land-use policies. Am. Sci. 67, 660-669. doi: 10.2307/2784 9531 studies which could encompass longer time-frames could present precious complementary information on forest composition and natural disturbance history at the millennial scale.

\section{DATA AVAILABILITY STATEMENT}

The datasets generated for this study are available on request to the corresponding author.

\section{AUTHOR CONTRIBUTIONS}

TE has conducted the research, data analysis and manuscript writing of this paper. DA and LS have participated significantly in the development of the methods and the revision of the manuscript. YB has participated by rendering the historical inventory data available and has participated with DA and LS in obtaining funding for the research project.

\section{FUNDING}

This work was financed by the Quebec's Nature and Technology Research Fund (FRQ-NT) and the Research Chair of the Inhabited Forest (Chaire de recherche sur la forêt habitée) of the University of Quebec at Rimouski (UQAR).

\section{ACKNOWLEDGMENTS}

We thank Archives Nationales du Québec (BAnQ) in Chicoutimi for providing us with Price Brothers \& Company forest inventory and maps.

Boucher, Y., Arseneault, D., and Sirois, L. (2006). Logging-induced change (19302002) of a preindustrial landscape at the northern range limit of northern hardwoods, eastern Canada. Can. J. For. Res. 36, 505-517. doi: 10.1139/ $\mathrm{x} 05-252$

Boucher, Y., Arseneault, D., and Sirois, L. (2009a). Logging history (1820-2000) of a heavily exploited southern boreal forest landscape: insights from sunken logs and forestry maps. For. Ecol. Manage. 258, 1359-1368. doi: 10.1016/j.foreco. 2009.06.037

Boucher, Y., Arseneault, D., and Sirois, L. (2009b). La forêt préindustrielle $\mathrm{du}$ Bas-Saint-Laurent et sa transformation (1820-2000): implications pour l'aménagement écosystémique. Nat. Can. 133, 60-69.

Boucher, Y., Arseneault, D., Sirois, L., and Blais, L. (2009c). Logging pattern and landscape changes over the last century at the boreal and deciduous forest transition in Eastern Canada. Landsc. Ecol. 24, 171-184. doi: 10.1007/s10980008-9294-8

Boucher, Y., Auger, I., Noël, J., Grondin, P., and Arseneault, D. (2017). Fire is a stronger driver of forest composition than logging in the boreal forest of eastern Canada. J. Veg. Sci. 28, 57-68. doi: 10.1111/jvs.12466

Boucher, Y., Grondin, P., and Auger, I. (2014). Land use history (1840-2005) and physiography as determinants of southern boreal forests. Landsc. Ecol. 29, 437-450. doi: 10.1007/s10980-013-9974-x

Boulanger, Y., and Arseneault, D. (2004). Spruce budworm outbreaks in eastern Quebec over the last 450 years. Can. J. For. Res. 34, 1035-1043. doi: 10.1139/ x03-269

Brisson, J., and Bouchard, A. (2003). In the past two centuries, human activities have caused major changes in the tree species composition of southern Québec, Canada. Écoscience 10, 236-246. doi: 10.1080/11956860.2003.11682771 
Bürgi, M., Russell, E. W. B., and Motzkin, G. (2000). Effects of postsettlement human activities on forest composition in the north-eastern United States: a comparative approach. J. Biogeogr. 27, 1123-1138. doi: 10.1046/j.1365-2699. 2000.00484.x

Canham, C. D., Rogers, N., and Buchholz, T. (2013). Regional variation in forest harvest regimes in the northeastern United States. Ecol. Appl. 23, 515-522. doi: 10.1890/12-0180.1

Cleland, D. T., Leefers, L. A., and Dickmann, D. I. (2001). "Ecology and management of aspen: a lake states perspective. paper presented at the sustaining aspen in western landscapes," in Symposium Proceedings of the 13-15 June 2000; Grand Junction, CO. Proceedings RMRS-P-18, Fort Collins, CO.

Danneyrolles, V., Dupuis, S., Arseneault, D., Terrail, R., Leroyer, M., de Römer, A., et al. (2017). Eastern white cedar long-term dynamics in eastern Canada: implications for restoration in the context of ecosystem-based management. For. Ecol. Manage. 400, 502-510. doi: 10.1016/j.foreco.2017. 06.024

Danneyrolles, V., Dupuis, S., Fortin, G., Leroyer, M., de Römer, A., Terrail, R., et al. (2019). Stronger influence of anthropogenic disturbance than climate change on century-scale compositional changes in northern forests. Nat. Commun. 10:1265. doi: 10.1038/s41467-019-09265-z

Dupuis, S., Arseneault, D., and Sirois, L. (2011). Change from pre-settlement to present-day forest composition reconstructed from early land survey records in eastern Québec, Canada. J. Veg. Sci. 22, 564-575. doi: 10.1111/j.1654-1103. 2011.01282.x

Ellis, E. C., Klein Goldewijk, K., Siebert, S., Lightman, D., and Ramankutty, N. (2010). Anthropogenic transformation of the biomes, 1700 to 2000. Glob. Ecol. Biogeogr. 19, 589-606. doi: 10.1111/j.1466-8238.2010.00540.x

Environment Canada (2019). Canadian Climate Normals and Averages 1981-2010. Available online at: http://climate.weather.gc.ca/climate_normals/index_e.html (accessed January 1, 2019).

Etheridge, D. A., MacLean, D. A., Wagner, R. G., and Wilson, J. S. (2005). Changes in landscape composition and stand structure from 1945-2002 on an industrial forest in New-Brunswick, Canada. Can. J. For. Res. 35, 1965-1977. doi: 10.1139/ x05-110

Fahey, T. J., and Reiners, W. A. (1981). Fire in the forests of Maine and New Hampshire. Bull. Torrey Bot. Club 108, 362-373. doi: 10.2307/2484716

Fei, S., and Steiner, K. C. (2008). Relationships between advance oak regeneration and biotic and abiotic factors †. Tree Physiol. 28, 1111-1119. doi: 10.1093/ treephys/28.7.1111

Fisichelli, N. A., Frelich, L. E., and Reich, P. B. (2014). Temperate tree expansion into adjacent boreal forest patches facilitated by warmer temperatures. Ecography 37, 152-161. doi: 10.1111/j.1600-0587.2013.00197.x

Foley, J. A., DeFries, R., Asner, G. P., Barford, C., Bonan, G., Carpenter, S. R., et al. (2005). Global consequences of land use. Science 309, 570-574. doi: 10.1126/ science. 1111772

Fortin, G. (2018). Transformation de la Composition de la Forêt de la Péninsule Gaspésienne au Cours du XXème Siècle. Doctorat en Biologie, thesis, Université du Québec à Montréal, Montreal, QC.

Fortin, J.-C., Lechasseur, A., Morin, Y., Harvey, F., Lemay, J., and Tremblay, Y. (1993). Histoire du Bas-Saint-Laurent. Quebec, QC: Québec Publishing.

Foster, D. R. (1992). Land-use history (1730-1990) and vegetation dynamics in central New England, USA. J. Ecol. 80, 753-772. doi: 10.2307/226 0865

Foster, D. R., Motzkin, G., and Slater, B. (1998). Land-use history as long-term broad-scale disturbance: regional forest dynamics in central New England. Ecosystems 1, 96-119. doi: 10.1007/s100219900008

Foster, D. R., Swanson, F. J., Aber, J. D., Burke, I., Brokaw, N. V. L., Tilman, D., et al. (2003). The importance of land-use legacies to ecology and conservation. Bioscience 53, 77-88. doi: 10.1641/00063568(2003)053[0077:TIOLUL]2.0.CO;2

Frelich, L. E. (2002). Forest Dynamics and Disturbance Regimes: Studies From Temperate Evergreen-Deciduous Forests. New York, NY: Cambridge University Press.

Frelich, L. E., and Lorimer, C. G. (1991). Natural disturbance regimes in hemlockhardwood forests of the upper great lakes region. Ecol. Monogr. 61, 145-164. doi: $10.2307 / 1943005$
Friedman, S. K., and Reich, P. B. (2005). Regional legacies of logging: departure from presettlement forest conditions in northern Minnesota. Ecol. Appl. 15, 726-744. doi: 10.1890/04-0748

Fuller, J. L., Foster, D. R., McLachlan, J. S., and Drake, N. (1998). Impact of human activity on regional forest composition and dynamics in central New England. Ecosystems 1, 76-95. doi: 10.1007/s100219900007

Gimmi, U., Wohlgemuth, T., Rigling, A., Hoffmann, C. W., and Bürgi, M. (2010). Land-use and climate change effects in forest compositional trajectories in a dry Central-Alpine valley. Ann. For. Sci. 67:701. doi: 10.1051/forest/2010026

Gray, D. R. (2008). The relationship between climate and outbreak characteristics of the spruce budworm in eastern Canada. Clim. Change 87, 361-383. doi: 10.1007/s10584-007-9317-5

Grondin, P., Blouin, J., and Racine, P. (1999). Rapport de Classification Écologique du Sous-Domaine Bioclimatique de la Sapinière à Bouleau Jaune de L'est. Quebec, QC: Ministère de l'Énergie et des Ressources naturelles.

Hall, B., Motzkin, G., Foster, D. R., Syfer, M., and Burk, J. (2002). Three hundred years of forest and land-use change in Massachusetts, USA. J. Biogeogr. 29, 1319-1335. doi: 10.1046/j.1365-2699.2002.00790.x

Harvey, B. D., Leduc, A., Gauthier, S., and Bergeron, Y. (2002). Stand-landscape integration in natural disturbance-based management of the southern boreal forest. For. Ecol. Manage. 155, 369-385. doi: 10.1016/S0378-1127(01)00573-4

Hébert, A. D. (1938). Rapport Concernant les Opérations Aériennes de Val Brillant Comté de Matapédia. Montreal, QC: BAnQ Grande Bibliothèque.

Heitzman, E., Pregitzer, K. S., and Miller, R. O. (1997). Origin and early development of northern white-cedar stands in northern michigan. Can. J. For. Res. 27, 1953-1961. doi: 10.1139/x97-157

Houghton, R. A. (1994). The worldwide extend of land-use change. Bioscience 44, 305-313. doi: 10.2307/1312380

Jackson, S. M., Pinto, F., Malcolm, J. R., and Wilson, E. R. (2000). A comparison of pre-European settlement (1857) and current (1981-1995) forest composition in central Ontario. Can. J. For. Res. 30, 605-612. doi: 10.1139/x99-242

Keenan, R. J., and Kimmins, J. P. (1993). The ecological effects of clear-cutting. Environ. Rev. 1, 121-144. doi: 10.1139/a93-010

Krankina, O. N., Houghton, R. A., Harmon, M. E., Hogg, E., Butman, D., Yatskov, M., et al. (2005). Effects of climate, disturbance, and species on forest biomass across Russia. Can. J. For. Res. 35, 2281-2293. doi: 10.1139/x05-151

Landhäusser, S. M., Deshaies, D., and Lieffers, V. J. (2010). Disturbance facilitates rapid range expansion of aspen into higher elevations of the Rocky Mountains under a warming climate. J. Biogeogr. 37, 68-76. doi: 10.1111/j.1365-2699.2009. 02182.x

Landres, P. B., Morgan, P., and Swanson, F. J. (1999). Overview of the use of natural variability concepts in managing ecological systems. Ecol. Appl. 9, 1179-1188. doi: $10.2307 / 2641389$

Leahy, M. J., and Pregitzer, K. S. (2003). A comparison of presettlement and present-day forest in northeastern lower Michigan. Am. Midland Nat. 149, 71-89. doi: 10.1674/0003-0031(2003)149[0071:ACOPAP]2.0.CO;2

Lindenmayer, D. B., and Franklin, J. F. (2002). Conserving Forest Biodiversity. Washington, DC: Island Press.

Lorimer, C. G. (1977). The presettlement forest and natural disturbance cycle of northeastern maine. Ecology 58, 139-148. doi: 10.2307/1935115

Lorimer, C. G. (2001). Historical and ecological roles of disturbance in eastern North American forests: 9,000 years of change. Wildl. Soc. Bull. 29, 425-439.

Lorimer, C. G., and White, A. S. (2003). Scale and frequency of natural disturbances in the northeastern US: implications for early successional forest habitats and regional age distributions. For. Ecol. Manage. 185, 41-64. doi: 10.1016/S03781127(03)00245-7

Montoro Girona, M., Morin, H., Lussier, J.-M., and Ruel, J.-C. (2019). Post-cutting mortality following experimental silvicultural treatments in unmanaged boreal forest stands. Front. For. Glob. Change 2:4. doi: 10.3389/ffgc.2019.00004

Nie, Z., MacLean, D. A., and Taylor, A. R. (2018). Forest overstory composition and seedling height influence defoliation of understory regeneration by spruce budworm. For. Ecol. Manage. 409, 353-360. doi: 10.1016/j.foreco.2017.11.033

Nolet, P., Delagrange, S., Bouffard, D., Doyon, F., and Forget, E. (2008). The successional status of sugar maple (Acer saccharum), revisited. Ann. For. Sci. 65, 208-208. doi: 10.1051/forest:2007091

Nowacki, G. J., and Abrams, M. D. (2015). Is climate an important driver of postEuropean vegetation change in the Eastern United States? Glob. Change Biol. 21, 314-334. doi: $10.1111 /$ gcb. 12663 
Palik, B. J., and Pregitzer, K. S. (1992). A comparison of presettlement and presentday forests on two Bigtooth aspen-dominated landscape in northern lower Michigan. Am. Midland Nat. 127, 327-338. doi: 10.2307/2426539

Payette, S., Filion, L., and Delwaide, A. (1990). Disturbance regime of a cold temperate forest as deduced from tree-ring patterns: the Tantaré ecological reserve, Quebec. Canadian. J. For. Res. 20, 1228-1241. doi: 10.1139/x 90-162

Plieninger, T., Draux, H., Fagerholm, N., Bieling, C., Bürgi, M., Kizos, T., et al. (2016). The driving forces of landscape change in Europe: a systematic review of the evidence. Land Use Policy 57, 204-214. doi: 10.1016/j.landusepol.2016. 04.040

Price Brothers and Company Limited (1944). Working - Plan Report for Rimouski Establishment. Chicoutimi, QC: Archives Nationales du Québec.

Proulx, L. (1985). Les Chantiers Forestiers de la Rimouski (1930-1940), Techniques Traditionnelles et Culture Matérielle. Rimouski, QC: Université du Québec à Rimouski (UQAR).

R Development Core Team (2016). R: A Language and Environment for Statistical Computing. Vienna: R Foundation for Statistical Computing.

Robitaille, A., and Saucier, J.-P. (1998). Paysage Régionaux du Québec Méridional, Direction de la Gestion des Stock Forestiers et Direction des Relations Publiques, Ministère des Ressources Naturelles du Québec. Quebec, QC: Publication du Québec.

Rowe, J. S. (1972). Forest Regions of Canada. Ottawa, ON: Information Canada.

Ruel, J.-C., Lussier, J.-M., Morissette, S., and Ricodeau, N. (2014). Growth response of northern white-cedar (Thuja occidentalis) to natural disturbances and partial cuts in mixedwood stands of Quebec, Canada. Forests 5:1194. doi: 10.3390/ f5061194

Siccama, T. G. (1971). Presettlement and present forest vegetation in northern Vermont with special reference to Chittenden county. Am. Midland Nat. 85, 153-172. doi: 10.2307/2423919

Simard, I., Morin, H., and Lavoie, C. (2006). A millennial-scale reconstruction of spruce budworm abundance in Saguenay, Quéebec, Canada. Holocene 16, 31-37. doi: 10.1191/0959683606hl904rp

Steffen, W., Sanderson, R. A., Tyson, P. D., Jäger, J., Matson, P. A., Moore, B., et al. (2004). Global Change and the Earth System - A Planet Under Pressure. Berlin: Springer-Verlag.

Terrail, R. (2013). Influence de la Colonisation sur les Transformations $d u$ Paysage Forestier Depuis L'époque Préindustrielle Dans l'Est du Québec
(Canada). Doctoral, thesis, Université du Québec a Rimouski (UQAR), Rimouski, QC.

Terrail, R., Morin-Rival, J., Fortin, M. J., and Arseneault, D. (2019). Effects of 20th century settlement fires on landscape structure and forest composition in Eastern Quebec, Canada. J. Veg. Sci. 31, 40-52. doi: 10.1111/jvs.12832

Trumbore, S., Brando, P., and Hartmann, H. (2015). Forest health and global change. Science 349, 814-818. doi: 10.1126/science.aac6759

Turner, M. G. (2010). Disturbance and landscape dynamics in a changing world. Ecology 91, 2833-2849. doi: 10.1890/10-0097.1

Vayreda, J., Martinez-Vilalta, J., Gracia, M., Canadell, J. G., and Retana, J. (2016). Anthropogenic-driven rapid shifts in tree distribution lead to increased dominance of broadleaf species. Glob. Change Biol. 22, 3984-3995. doi: 10.1111/ gcb.13394

White, M. A., and Mladenoff, D. J. (1994). Old-growth forest landscape transition from pre-European settlement to present. Landsc. Ecol. 9, 191-205. doi: 10. 1007/BF00134747

White, P., and Jentsch, A. (2001). "The search for generality in studies of disturbance and ecosystem dynamics," in Progress in Botany, Vol. 62, eds K. Esser, U. Lüttge, J. W. Kadereit, and W. Beyschlag (Berlin: Springer), 399-450.

Whitney, G. G. (1994). From Coastal Wilderness to Fruited Plain: A History of Environmental Change in Temperate North America, 1500 to the Present. Cambridge: Cambridge University Press.

Whitney, G. G., and DeCant, J. P. (2003). Physical and historical determinants of the pre- and post-settlement forests of northwestern Pennsylvania. Can. J. For. Res. 33, 1683-1697. doi: 10.1139/x03-079

Williams, G. W. (2000). Introduction to aboriginal fire use in North America. Fire Manage. Today 60, 8-12.

Conflict of Interest: The authors declare that the research was conducted in the absence of any commercial or financial relationships that could be construed as a potential conflict of interest.

Copyright (c) 2020 Elzein, Arseneault, Sirois and Boucher. This is an open-access article distributed under the terms of the Creative Commons Attribution License (CC BY). The use, distribution or reproduction in other forums is permitted, provided the original author(s) and the copyright owner(s) are credited and that the original publication in this journal is cited, in accordance with accepted academic practice. No use, distribution or reproduction is permitted which does not comply with these terms. 


\section{APPENDIX}

A Abies balsamea

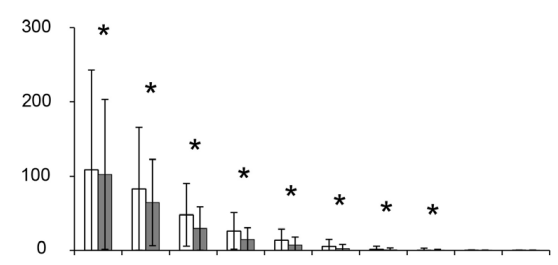

B Picea spp.

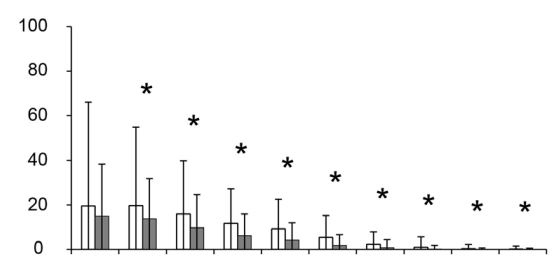

c Thuja occidentalis

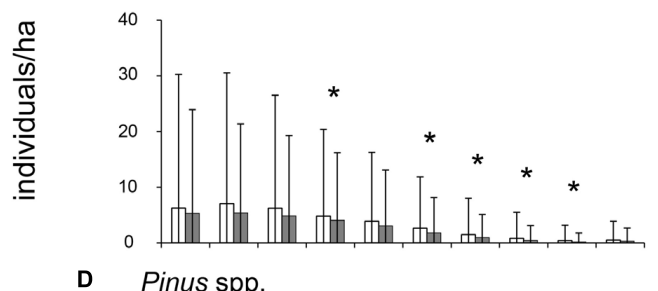

D Pinus spp.

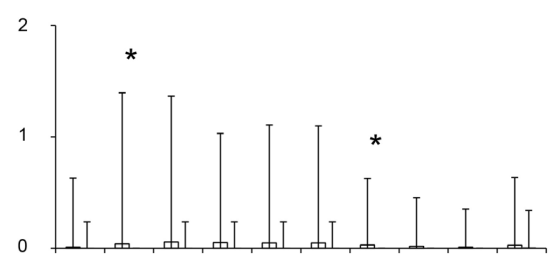

E Larix laricina

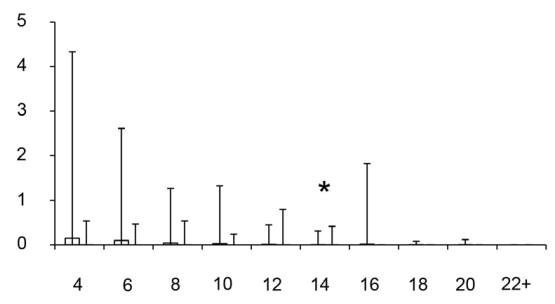

F Betula papyrifera

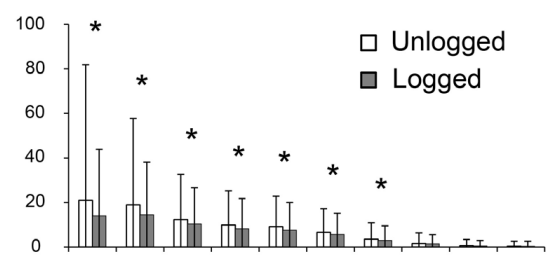

G Betula alleghaniensis

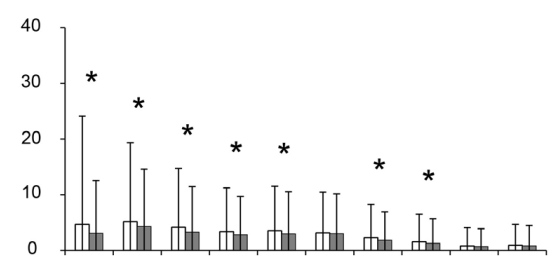

H Acerspp.

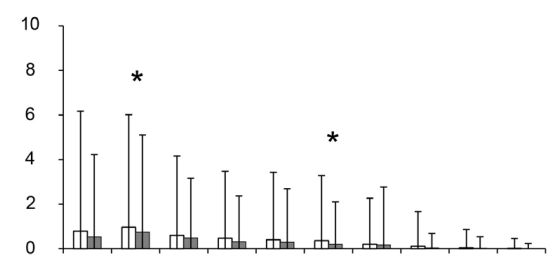

I Populus spp.

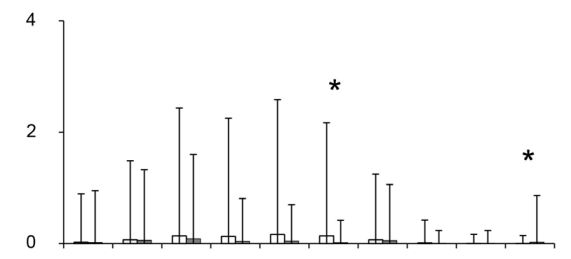

J Fraxinus spp.

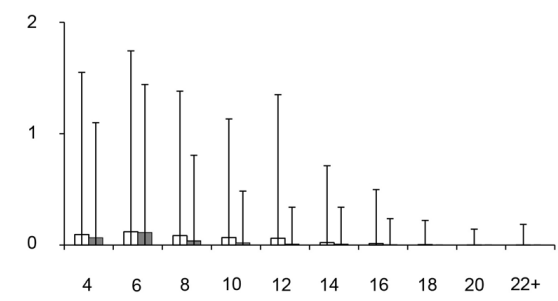

Diameter class (inch)

APPENDIX 1 | Stem density per diameter class per species in previously unlogged ( $N=14634)$ versus logged plots $(N=1822)$ in $1930-1931$. Bars represent standard deviation, Asterisks ${ }^{*}$ ) indicate a statistically significant difference in stem density between unlogged and logged plots for a given diameter class (Wilcoxon test; $p<0.05)$. 


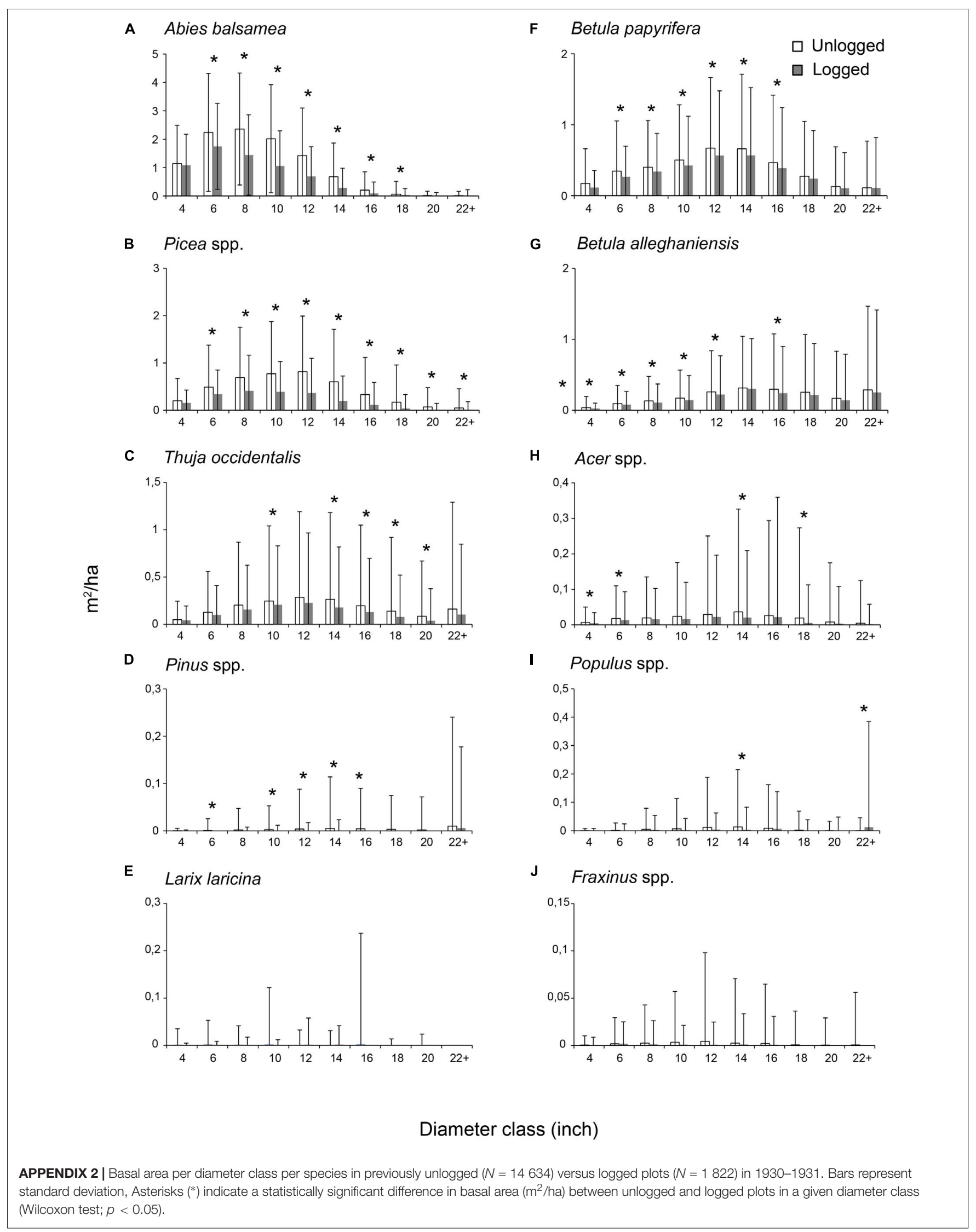

